\title{
CAUSES OF THE RECENT TURN IN CONSTITUTIONAL INTERPRETATION
}

\author{
CHRISTOPHER H. SCHROEDER $\dagger$
}

\section{INTRODUCTION}

Due Process. Equal Protection of the Laws. Commerce Among the Several States. The words and phrases of the Constitution that produce most interpretive disagreements are very old. Many, such as the Presentment Clause and the Vesting Clauses, can be found in the Constitution as it existed in 1793. Others, including the Privileges and Immunities Clause and Equal Protection Clauses of the Fourteenth Amendment, were added to the Constitution immediately after the Civil War. None of these clauses has changed since the day it was ratified.

No similar stability has attended the Supreme Court's understanding of what these clauses mean. Sometimes the Free Exercise Clause of the First Amendment has meant that states must make reasonable accommodations for religious practices in administering facially neutral laws, while at other times it has meant that states need not do so. ${ }^{1}$ Sometimes the Enforcement Clause of the Fourteenth Amendment has meant that Congress has special leeway in crafting programs designed to ameliorate the effects of past discrimination, while at other times it has meant that Congress has no more leeway

Copyright $(2) 2001$ by Christopher H. Schroeder.

$\dagger$ Charles S. Murphy Professor of Law, Duke University School of Law. This Essay is based on a paper presented at the Constitution in Exile conference hosted by the Program in Public Law at Duke University School of Law on October 5-7, 2000. My thanks to Neal Devins, Keith Whittington, and the other conference participants for valuable criticisms and comments.

1. Compare Sherbert v. Verner, 374 U.S. 398, 408-09 (1963) (holding that a neutral, generally applicable state law barring unemployment compensation to individuals who did not accept suitable work when offered could not be applied to a Seventh Day Adventist who refused to work on Saturdays for religious reasons), with Employment Div., Dept. of Human Res. v. Smith, 494 U.S. 872, 884-85 (1990) (holding that a neutral, generally applicable state law criminalizing drug use could be applied to Native Americans who used peyote in a religious ceremony). 
than the states. ${ }^{2}$ Sometimes the Tenth Amendment has meant that the states are protected from federal wage and hour standards, while at other times it has not. ${ }^{3}$ Moreover, when the Constitution has not protected states from the application of federal wage and hour standards, sometimes sovereign immunity has protected the states from employee lawsuits complaining of the violation of the Fair Labor Standards Act, while at other times it has not. ${ }^{4}$ And so on.

Such shifts in meaning have become part and parcel of contemporary history. The Supreme Court's recent interpretive changes vary in magnitude, but cumulatively they leave little doubt that the Rehnquist Court reads the Constitution in ways markedly different from the Warren Court. Of course, all these changes have generated considerable debate over whether the new meanings are better than the old. These shifts in meaning also have brought renewed interest in the question of constitutional change. What best explains why interpretive positions change? What do these changes say about the nature of legal reasoning? This Essay explores the issue of constitutional change with respect to one major class of changes: those introduced by the Rehnquist Court's federalism jurisprudence.

\section{The CURRent Constitutional MOMENT}

\section{A. Recent Doctrinal Changes}

In the recent past, the Court interpreted the Constitution to protect a woman's right to choose, ${ }^{5}$ to grant Congress broad powers un-

2. Compare Metro Broad., Inc. v. FCC, 497 U.S. 547, 564-65 (1990) (applying intermediate scrutiny to minority preference policies at the Federal Communications Commission), with Adarand Constructors, Inc. v. Pena, 515 U.S. 200, 223-24 (1995) (applying strict scrutiny to a federal set-aside program for minority contractors).

3. Compare Nat'l League of Cities v. Usery, 426 U.S. 833, 851 (1976) (finding that the minimum wage and hour provisions of the Fair Labor Standards Act as applied to employees of state and local governments were unconstitutional), with Maryland v. Wirtz, 392 U.S. 183, 19596 (1968) (upholding the Fair Labor Standards Act as applied to state-operated schools and hospitals), and Garcia v. San Antonio Metro. Transit Auth., 469 U.S. 528, 531 (1985) (overruling Usery and upholding the minimum wage and hour provisions of the Fair Labor Standards Act as applied to a municipal transit authority).

4. See Alden v. Maine, 527 U.S. 706, 739-40 (1999) (holding that a state could not be sued in either federal or state court for violations of the Fair Labor Standards Act unless it had waived sovereign immunity, even though the Fair Labor Standards Act applies to state employees).

5. Roe v. Wade, 410 U.S. 113, 163 (1973) (ruling that a patient can obtain an abortion without interference from states before the fetus is viable). 
der the Commerce Clause to regulate and criminalize intrastate activities, ${ }^{6}$ to authorize congressional abrogation of state sovereign immunity pursuant to Congress's Commerce Clause powers, ${ }^{7}$ and to recognize a distinction between discrimination designed to ameliorate the effects of prior invidious discrimination and invidious discrimination itself.

Today, all these doctrines have been overruled or noticeably altered, with the exception of the "essential holding" of Roe v. Wade. Even that counterexample attests to a sea change in the Court's approach to constitutional interpretation. To affirm Roe, the extraordinary joint opinion in Planned Parenthood v. Casey ${ }^{10}$ relied heavily on stare decisis, rather than on a straightforward reassertion of Roe's reasoning. ${ }^{11}$ Casey thus was a case in which dispositional conservatism prevailed over a more ideologically aggressive brand, not a case in

6. See, e.g., Perez v. United States, 402 U.S. 146, 152-53 (1971) (finding that "extortionate credit transactions" were among the class of activities Congress could regulate in the absence of particular proof that the activity affects interstate commerce).

7. See, e.g., Pennsylvania v. Union Gas Co., 491 U.S. 1, 19 (1989) (determining that "the special nature of the power conferred" by the Commerce Clause allows Congress to supersede state sovereign immunity when legislating pursuant to the Commerce Clause). Under current interpretations, Congress can abrogate state sovereign immunity when enforcing provisions of the Fourteenth Amendment, but not when exercising its Commerce Clause powers. Alden, 527 U.S. at 733 .

8. See, e.g., Regents of the Univ. of Cal. v. Bakke, 438 U.S. 265, 271-72 (1978) (opinion of Powell, J.) (upholding an order invalidating the special admissions program at the University of California, Davis, School of Medicine). In Bakke, a fractured decision in which the Justices split 4-1-4, Justice Powell (writing alone) announced the judgment of the Court. Justice Powell wrote that some preference for race is acceptable in higher education because diversity constitutes a compelling state interest. Id. at 314-15. Justice Brennan's opinion for four of the Justices stated that affirmative action in medical school admissions does not stigmatize and that affirmative action is justified when it redresses past discrimination. Id. at 360-62.

9. See United States v. Lopez, 514 U.S. 549, 567 (1995) (limiting Congress's powers under the Commerce Clause to regulate and criminalize intrastate activities); Alden, 527 U.S. at 73940 (limiting congressional authority to abrogate state sovereign immunity under the Commerce Clause); City of Richmond v. J.A. Croson Co., 488 U.S. 469, 507 (1989) (invalidating, on Due Process Clause grounds, a plan intended to remedy discrimination because the plan was not linked to identified discrimination). For a discussion of other doctrines that have changed, see supra notes 1-4 and accompanying text.

10. 505 U.S. 833 (1992).

11. Id. at 853 (O'Connor, J., plurality opinion):

While we appreciate the weight of the arguments made on behalf of the State in the cases before us, arguments which in their ultimate formulation conclude that Roe should be overruled, the reservations any of us may have in reaffirming the central holding of Roe are outweighed by the explication of individual liberty we have given combined with the force of stare decisis. 
which the constitutional philosophy of the Warren Court's opinion continued to attract majority support on its own. ${ }^{12}$

Many of the opinions signaling doctrinal change have been 5-4 or 6-3 decisions. ${ }^{13}$ These splits often are interpreted as occurring along a liberal to conservative continuum, and as signifying that the Court is just as divided as (and perhaps even more divided than) the Court of thirty years ago. ${ }^{14}$ Neither the apparent continuation of a liberal/conservative division nor the closeness of many of the Court's opinions ought to mask the fact that the Court as a whole is a very different body from the Court of thirty years ago. The center of gravity of the issues the Court takes up with its discretionary jurisdiction has shifted toward the conservative end of the spectrum. The cuttingedge questions that confronted the Warren Court probed the limits of an expanding set of civil liberties, ${ }^{15}$ of the power of citizens to challenge actions of their government, ${ }^{16}$ and of the federal government's nearly total authority to establish national policies. ${ }^{17}$ In contrast, contemporary cutting-edge decisions test how far protections for civil

12. See Christopher H. Schroeder, A Conservative Court? Yes, 1993 PUB. INT. L. REV. 127, 130-146 (discussing three types of conservatism evident in recent Court decisions: judicial role conservatism, a desire not to upset majoritarian decisions; ideological conservatism, a desire to implement a particular conservative ideology of limited government, a greater role for religion in public life, and a strong executive; and dispositional conservatism, a desire to respect existing practices and to avoid decisions based on abstract rules). Casey represented a triumph of dispositional conservatism over the other two forms. Id. at 142 .

13. See Alden, 527 U.S. at 739-40 (5-4 decision); Lopez, 514 U.S. at 567 (5-4 decision); Croson, 488 U.S. at 507 (6-3 decision).

14. See Linda Greenhouse, Ideas \& Trends: Divided They Stand, The High Court and The Triumph of Discord, N.Y. TIMES, July 15, 2001, § 4, at 1 (stating that the 2000 Term saw onethird of the Court's seventy-nine cases decided by 5-4 votes, a "higher proportion than any time in memory"); Charles Lane \& Amy Goldstein, At High Court, a Retirement Watch, WASH. POST, June 17, 2001, at A4 (describing the Court as divided along liberal and conservative lines and discussing the increasing likelihood that Chief Justice Rehnquist and Justice O'Connor will retire).

15. See, e.g., Griswold v. Connecticut, 381 U.S. 479, 485 (1965) (invalidating a law that forbade the use of contraceptives).

16. See, e.g., Flast v. Cohen, 392 U.S. 83, 102 (1968) (upholding a taxpayer's standing to challenge federal subsidies to parochial schools under the Establishment Clause).

17. See, e.g., Maryland v. Wirtz, 392 U.S. 183, 195-96 (1968) (holding that the "enterprise concept" of the Fair Labor Standards Act was constitutionally valid under the Commerce Clause). 
liberties should be narrowed, ${ }^{18}$ standing restricted, ${ }^{19}$ and federal authority limited. ${ }^{20}$

This reorientation has been under way for a number of years, notwithstanding the fact that the developments of the past decade have attracted the most attention. While the Burger Court has been described as the "counter-revolution that wasn't," tively halted the extension of many Warren Court precedents. The Burger Court may not have marched off in new directions, but its lack of enthusiasm for Warren Court precedent helped prepare the way for the Rehnquist Court's interpretive shift. The result is that in most areas of constitutional jurisprudence today, the vectors of jurisgenerative energy point in directions that lead to conservative results, not liberal ones. Put in political science terms, the core constituencies of the Court have changed in the last three decades. They have shifted

18. See, e.g., Bowers v. Hardwick, 478 U.S. 186, 195-96 (1986) (ruling that there is no privacy right protecting consensual acts of homosexual sex in a private home).

19. See, e.g., Lujan v. Nat'l Wildlife Fed'n, 497 U.S. 871, 889 (1990) (denying standing to plaintiffs challenging land-use decisions by a federal agency because the plaintiffs had not alleged with sufficient specificity that they used the particular lands affected).

20. See, e.g., United States v. Lopez, 514 U.S. 549, 567 (1995) (limiting Congress's powers under the Commerce Clause to regulate and criminalize intrastate activities). The contrast between the present Court and the 1970s Court is starkly illustrated by San Antonio Independent School District v. Rodriguez, 411 U.S. 1 (1973). The Rodriguez Court came within one vote of affirming a district court decision finding wealth a suspect classification and education a fundamental interest for purposes of equal protection analysis. Id. at 62-133. Advocates of more equitable public school financing - and of more aggressive equal protection review of state and local laws - had viewed their chances in the Supreme Court with some optimism. Part of the reason for their optimism was a California state court decision, Serrano v. Priest, 487 P.2d 1241 (Cal. 1971), rendered two years prior to Rodriguez. The Serrano court concluded that the plaintiffs' complaint adequately alleged that California's public school financing system touched upon a fundamental interest and that a student's entitlement to this fundamental interest was conditioned upon wealth. $I d$. at 1263 . The court held that the California public school financing system would not withstand strict scrutiny if the plaintiffs could prove the allegations contained in their complaint. Id. Earlier Warren Court decisions seemed to suggest that the Supreme Court might view a similar challenge favorably. See Judith Areen \& Leonard Ross, The Rodriguez Case: Judicial Oversight of School Finance, 1973 SUP. CT. REV. 33, 33 (observing that conservative scholar Philip Kurland had "noted (and deplored)... [that] the 'activist' decisions of the Warren Court provided the straight edge and compass for the logical construction of an argument for court-ordered reform of school finance-in Kurland's words, 'the easy case for equal educational opportunity"'). Today, it is unlikely that anyone supporting such an agenda would seek to litigate in the Supreme Court.

21. The Burger Court: The Counter-Revolution That Wasn't (Vincent Blasi ed., 1983). 
from labor unions, minorities, and women to a "well-to-do constituency.",22

The shift can be detected in attorneys' litigation strategies. Supporters of legal positions drawn from Warren Court precedent are reluctant to bring cases that might call those precedents into question. $^{23}$ In their place, those pursuing an agenda of undoing Warren Court precedents-by restricting federal power, by dismantling affirmative action programs, and by championing state autonomy-are eager to bring cases.

The conservative potential of the Rehnquist Court is not always fully realized. Such was the case in Casey, Dickerson, ${ }^{24}$ and Laidlaw. ${ }^{25}$ Nonetheless, such setbacks cannot hide the fact that the Court has staked out positions on a number of questions that are quite distinct from Warren Court precedent, nor can they hide the fact that liberal theories of constitutionalism are generally on the defensive for their inability to explain or justify Supreme Court decisions.

But how are scholars to characterize the current constitutional moment? Some commentators have ascribed an almost unprecedented significance to these doctrinal shifts. In this spirit, Michael Gerhardt writes that the Court's recent federalism decisions are of "historic proportions," creating a tension between Congress and the Court unseen since the Lochner era. ${ }^{26}$ New York Times Supreme Court reporter Linda Greenhouse sees a "revolution" occurring on

22. Mark Tushnet, The Supreme Court, 1998 Term-Foreword: The New Constitutional Order and the Chastening of Constitutional Aspiration, 113 HARV. L. REV. 29, 66 (1999). Were the most conservative implications of the Court's recent doctrine to gain the support of a majority of Justices, the Court's core constituency would shift to encompass even more social conservatives.

23. Sometimes plaintiffs who support progressive positions are placed in situations where they have no realistic alternatives. Such was the case when the University of Texas lost the Hopwood decision in the Fifth Circuit, which invalidated the university's affirmative action program in admissions. Hopwood v. Texas, 78 F.3d 932, 944 (5th Cir. 1996), cert. denied, Thurgood Marshall Legal Soc'y v. Hopwood, 518 U.S. 1033 (2001). Texas's program was similar to other programs established at universities throughout the country permitting the use of race as a criterion in admissions.

24. Dickerson v. United States, 530 U.S. 428, 444 (2000) (reaffirming the rule of Miranda v. Arizona, 384 U.S. 436 (1966), which held that a confession is inadmissible unless the defendant received a prior warning informing him of his constitutional rights).

25. Friends of the Earth, Inc. v. Laidlaw Envtl. Servs. (TOC), Inc., 528 U.S. 167, 183-84 (2000) (granting standing under the Clean Water Act to plaintiffs who used waterways downstream of a discharging facility and who cut back on that use because of their concerns that the water was polluted).

26. Michael J. Gerhardt, Federal Regulation in a Post-Lopez World: Some Questions and Answers, 30 ENVTL. L. REP. 10,980, 10,980 (2000). 
the Court. ${ }^{27}$ Former United States Solicitor General Seth Waxman argues that "constitutional adjudication has undergone a thoroughgoing paradigm shift." ${ }^{28}$ Others see a distinct change, but a change that has already worked its most dramatic departures from the past. Mark Tushnet, for example, writes that although we are in a "new constitutional order," it is an order within which the current Court "will undertake no dramatic initiatives" nor effectuate many "dramatic retrenchments on established doctrine." ${ }^{29}$ In keeping with Tushnet's assessment, Frederick P. Lewis argues that core Warren Court decisions will remain intact because contemporary society finds them to be highly functional. ${ }^{30}$ Others take issue with the argument that the present is so sharply distinguishable from the past. Kathleen Sullivan thus finds this Court "not easy to classify," noting that in many areas of its jurisprudence, the Court has issued opinions better described as liberal than conservative, and that majorities in divided cases can be composed of members of the liberal and the conservative wings. ${ }^{31}$

The entire corpus of Supreme Court decisions indeed may be too diffuse for easy characterization as liberal or conservative. Even if every doctrinal dispute could be described as occurring along a single liberal-conservative dimension, it is questionable whether this dimension can be described the same way in all disputes. It thus seems improbable that all disputes can be seen as specific instances of a global struggle between liberalism and conservatism. There is one area of constitutional dispute, however, where the nature of the doctrinal shift, if not its magnitude, has come into sharp focus. That area involves questions of federalism.

New York v. United States ${ }^{32}$ first signaled the Court's shift toward increased protection for the states..$^{33}$ In the subsequent Brady Act liti-

27. Greenhouse, supra note $14, \S 4$, at 1 ("There is a revolution in progress at the court, with Chief Justice William H. Rehnquist and Justices Antonin Scalia, Sandra Day O'Connor, Anthony M. Kennedy and Clarence Thomas challenging long-settled doctrines governing statefederal relations, the separation of powers, property rights and religion.").

28. Seth Waxman, Defending Congress, 79 N.C. L. REV. 1073, 1075-76 (2001).

29. Tushnet, supra note 22, at 64.

30. Frederick P. LeWIS, The CONTEXT of Judicial ACtivism: The ENDURANCE of THE WARREN COURT LEGACY IN A CONSERVATIVE AGE 125-28 (1999).

31. Kathleen M. Sullivan, A Court Not Easy to Classify, N.Y. TIMES, June 29, 2000, at A31.

32. 505 U.S. 144 (1992).

33. Id. at 149 (holding that Congress may use incentives to encourage the states to dispose of the radioactive waste within their borders, but that Congress may not compel the states to do so). Although Justice O'Connor's opinion in New York was anticipated by her earlier concurrence in FERC v. Mississippi, 456 U.S. 742, 775-97 (1982) (O'Connor, J., concurring in part, dis- 
gation, the Court further solidified state protection under the Tenth Amendment. ${ }^{34}$ The Court also has protected state prerogatives by limiting the scope of powers assigned to the federal government. United States v. Lopez ${ }^{35}$ held that the Gun-Free School Zones Act of 1990 had gone beyond the reach of Congress's Commerce Clause powers. ${ }^{36}$ United States $v$. Morrison ${ }^{37}$ clarified and tightened the constitutional limitations on those powers. ${ }^{38}$ City of Boerne v. Flores ${ }^{39}$ imposed a proportionality restriction on Congress's powers under Section 5 of the Fourteenth Amendment. ${ }^{40}$ Kimel v. Florida Board of Regents $^{41}$ then held that federal legislation to eliminate workplace discrimination against the elderly was not "appropriate legislation" under that Amendment, and therefore could not be applied against the states by their employees. ${ }^{42}$ Seminole Tribe v. Florida ${ }^{43}$ and Alden $v$. Maine $^{44}$ found a residual concept of state sovereignty to be an implicit limitation on federal authority, protecting state autonomy far more robustly than the Eleventh Amendment's text might suggest. ${ }^{45}$ Indica-

senting in part), New York was the first decision in which her federalism views commanded a majority.

34. Printz v. United States, 521 U.S. 898, 907-12 (1997) (ruling that Congress did not have the constitutional authority to impress either the state executive or the state legislature into its service).

35. 514 U.S. 549 (1995).

36. Id. at 567-68.

37. 529 U.S. 598 (2000).

38. See id. at 617 (barring Congress from regulating "noneconomic, violent criminal conduct based solely on that conduct's aggregate effect on interstate commerce").

39. 521 U.S. 507 (1997).

40. Id. at 533-34 (stating that the demands that the Religious Freedom Restoration Act made of state laws "reflect[ed] a lack of proportionality or congruence between the means adopted and the legitimate end to be achieved").

41. 528 U.S. $62(2000)$.

42. Id. at 91 (stating that because Congress failed to identify a pervasive pattern of age discrimination by the states, Congress had no reason to believe the "indiscriminate scope" of the Age Discrimination in Employment Act of 1967 was necessary). The Court extended the Boerne-Kimel line by holding that Congress could not subject the states to suit for violations of the Americans with Disabilities Act. Garrett v. Bd. of Trs. of the Univ. of Ala., 531 U.S. 356, 121 S. Ct. 955, 960 (2001).

43. 517 U.S. 44 (1996).

44. 527 U.S. $706(1999)$.

45. Seminole Tribe, 517 U.S. at 68 (holding that the Constitution, in its grant of federal judicial power, "'does not embrace authority to entertain a suit brought by private parties against a State without consent given'” (quoting Ex parte New York, 256 U.S. 490, 497 (1921))); Alden, 527 U.S. at 713 (concluding that while the Constitution creates a national government with broad authority, the "founding document" also expressly acknowledges the sovereignty of states). 
tive of the centrality of these federalism decisions to the overall image of the current Court, scholars often refer to the present period as the Lopez or post-Lopez era. ${ }^{46}$ And except for New York v. United States, all of the federalism cases have been decided by an identical fiveJustice majority comprised of the conservative wing of the Court: Chief Justice Rehnquist and Justices O'Connor, Scalia, Kennedy, and Thomas.

\section{B. Gauging the Magnitude of the Federalism Decision Changes}

To shed some light on whether the federalism decisions are of historic proportions, we can utilize the distinction between revolutionary and nonrevolutionary constitutional change proposed by Bruce Ackerman. ${ }^{47}$ Ackerman's work on non-Article V constitutional amendments has been motivated in part by an interest in explaining how changes in constitutional interpretation can be both discontinuous with past interpretations, as judged by fair-minded application of the standard lawyers' tools of interpretation, yet also legitimate, despite the absence of formal amendment to the text of the Constitution itself. $^{48}$ Ackerman argues that for such discontinuous, or revolutionary, constitutional change to be legitimate, it needs to have proceeded through four distinct steps: signaling the existence of a significant constitutional dispute, proposing a change in constitutional meaning, mobilizing popular deliberation concerning the desirability of change and, finally, codifying the change through acceptance by public officials, including acceptance in Supreme Court doctrine. ${ }^{49}$

46. See, e.g., Lynn A. Baker, Conditional Federal Spending After Lopez, 95 ColuM. L. REV. 1911, 1919 (1995) (referring to the "post-Lopez era"); George D. Brown, Should Federalism Shield Corruption? - Mail Fraud, State Law and Post-Lopez Analysis, 82 CoRnell L. Rev. 225, 280 (1997) (referring to the "[p]ost-Lopez era"); Gerhardt, supra note 26, at 10,980 (referring to the "[p]ost-Lopez era"); Toni M. Massaro, Reviving Hugo Black? The Court's "Jot for Jot" Account of Substantive Due Process, 73 N.Y.U. L. REV. 1086, 1112 (1998) (referring to the "Lopez era"); Erik R. Neusch, Medical Marijuana's Fate in the Aftermath of the Supreme Court's New Commerce Clause Jurisprudence, 72 U. COLO. L. REV. 201, 239 (2001) (referring to the "pre-Lopez era"); Rachel Elizabeth Smith, United States v. Lopez: Reaffirming the Federal Commerce Power and Remembering Federalism, 45 CATH. U. L. REV. 1459, 1490 n.178 (1996) (referring to the "post-Lopez era").

47. 1 Bruce ACKerman, We the People: Foundations 19 (1991) (characterizing certain periods of constitutional history as involving "revolutionary reform" unlike periods of normal lawmaking).

48. Id. at 267-68 (contrasting the "classical" system of constitutional amendment through Article V of the Constitution with the "modern" system of constitutional amendment through the four steps of signaling, proposing, deliberating, and codifying for legitimacy).

49. Id. at 269-90 (describing the four steps). 
Ackerman further suggests that observers can identify when revolutionary change has occurred, and, hence, when some version of the four-step process is necessary to legitimize that change, by employing a thought experiment to test whether observed changes might be explicable simply by application of legal reasoning. The thought experiment involves a "ten-year test." ${ }^{10}$ As applied to the recent federalism changes, the experiment is this: Imagine traveling backward through time to 1990. Ask a thoughtful constitutional lawyer of that day to look forward a decade and "speculate about the likely paths that [federalism doctrine] might take if it proceeded along an evolutionary course-one small step at a time. ${ }^{51}$ Then return to the present, and "consider whether existing [federalism] doctrines actually remain within this evolutionary envelope of possibility. If they do, you have witnessed a decade of normal evolutionary development; but if they have moved far beyond the envelope on many doctrinal fronts, there has been a juridical revolution ....,"52

The results of this thought experiment when applied to the federalism decisions are quite contestable..$^{53}$ This should not be surprising. People can disagree over results of the thought experiment even when it is applied to decades that present much stronger evidence of revolutionary change. For comparison with the current period, consider the 1930s. That decade ought to be an easy case; in fact, it constitutes one of the three revolutionary constitutional moments Professor Ackerman identifies. ${ }^{54}$ While most people would concede that the jurisprudential changes that occurred in the 1930s satisfied the tenyear test, some revisionists have argued persuasively that the "switch

50. Bruce Ackerman, Revolution on a Human Scale, 108 YALE L.J. 2279, 2287 (1999).

51. Id.

52. $I d$.

53. The ten-year test contains a number of ambiguities this Essay does not attempt to resolve. Along how many doctrinal fronts must decisions shift outside the "evolutionary envelope" to qualify as "many"? Federalism, for instance, might be one doctrinal front, or it might be several: the doctrines of Section 5 of the Fourteenth Amendment, of the Tenth Amendment, of the Eleventh Amendment, and of the Commerce Clause. Would movement on these four areas constitute movement on "many" fronts? How do you measure whether a doctrine has moved "far beyond" normal evolutionary development? The recent federalism cases strike a tone quite different than those of thirty years ago, but so far they have not affected the federal government's ability to execute policy like the 1930s Court's rejection of the First New Deal did.

54. 1 ACKERMAN, supra note 47, at 47-50 (stating that the New Deal amounted to a "successful struggle ... to place activist national government on solid constitutional foundation," and that the "Supreme Court repudiated its doctrinal defense of laissez-faire capitalism and began to build new constitutional foundations for activist national government"). 
in time" that marked the change in the New Deal Court was within the evolutionary envelope of such cases as Nebbia $v$. New York. ${ }^{55}$

The revisionist account of the 1930s has not yet carried the day in recharacterizing the 1930 s as a period of merely evolutionary change. The case in favor of the revolutionary interpretation remains the more convincing. ${ }^{56}$ Our 1990s thought experiment, however, suggests that the recent turn in constitutional interpretation is not nearly as sharp as the turn taken by the 1930s Court. Some of the recent changes quite arguably fit within the evolutionary envelope as viewed from 1990. In particular, the holding in New York v. United States on the scope of the Tenth Amendment may have been fairly anticipated after FERC v. Mississippi ${ }^{57}$ (and even more so after Gregory v. Ashcroft $).{ }^{58}$ On the other hand, other features of the emerging federalism doctrines would have been harder to anticipate. For instance, few would have predicted that the Court might uncover the nontextual residual notion of sovereignty that grounds the results in Seminole Tribe $e^{59}$ and Alden. To reach those results, the Court had to overrule its newly minted 1989 decision in Pennsylvania v. Union Gas Co. ${ }^{60}$ Still other decisions of the 1990s also may have been outside the evo-

55. 291 U.S. 502 (1934); see, e.g, BARRY CUSHMAN, RETHINKING THE NEW DEAL COURT: The Structure of a Constitutional Revolution 7 (1998) ("[W]hen the Court abandoned the old public/private distinction in Nebbia, then, it pulled a particularly important thread from [an interwoven] fabric [of constitutional doctrine].”); Richard D. Friedman, Switching Time and Other Thought Experiments: The Hughes Court and Constitutional Transformation, 142 U. PA. L. REV. 1891, 1922 (1994) (stating that Nebbia represented "a reaffirmation of the more liberal direction" the Court was taking in "its emphasis on the susceptibility to control for the public good of what had previously been deemed private"). For further discussion, see infra note 116 and accompanying text.

56. For an analysis and critique of this revisionism, see generally David A. Pepper, Against Legalism: Rebutting an Anachronistic Account of 1937, 82 MARQ. L. REV. 63 (1998).

57. 456 U.S. 742, 775-97 (1982) (O'Connor, J., concurring in part and dissenting in part); see also supra note 33 .

58. 501 U.S. 452, 470 (1991) (finding that in enacting the Age Discrimination in Employment Act of 1967 Congress did not intend to usurp the traditional state power to determine the necessary credentials of its officers); see also South Dakota v. Dole, 483 U.S. 203, 212 (1987) (O'Connor, J., dissenting) (emphasizing that Congress exceeded its spending power because the condition it placed on spending was not "reasonably related to the expenditure of federal funds").

59. Seminole Tribe v. Florida, 517 U.S. 44, 66 (1996) (overruling Pennsylvania v. Union Gas Co., 491 U.S. 1 (1989)). If reversing a decision that was just rendered fell within plausible evolutionary expectations, then it seems that few, if any, changes could be judged outside the evolutionary envelope.

60. 491 U.S. 1, 19 (1989) (holding that the Commerce Clause granted Congress the authority to supercede state sovereign immunity since the power to regulate interstate commerce "would be incomplete without the authority to render states liable in damages"). 
lutionary envelope. For example, although scholars had noted for years that the Court's post-Lochner interpretation of the Commerce Clause put almost no action beyond Congress's power, a number of them also had suggested that this interpretation was in tension with the Framers' understanding. ${ }^{61}$ So the invocation of some limitation on Commerce Clause authority might have been a possibility in 1990 . Nonetheless, nothing in the Court's opinions prior to Lopez pointed to the specific distinction the Court has erected to police those Commerce Clause boundaries. ${ }^{62}$

The results of the thought experiment are further complicated because the conditions under which the experiment should be conducted have not been specified fully. The course of jurisprudential development can be affected by strategic actions that influence who becomes a Supreme Court Justice..$^{63}$ Because of this, the shape of the evolutionary envelope ten years in the future will depend upon whether the president has taken successful strategic steps.

In particular, efforts to affect the Court through strategic appointments were part of the historical backdrop leading up to the changes of the 1990s. For several decades, conservatives had worked hard to create conditions favorable to achieving results like those in Lopez and Printz. Through organs such as the Federalist Society, the Cato Institute, various conservative public interest litigation centers and legal journals, conservatives made the case for Commerce Clause limitations and respect for state autonomy. ${ }^{64}$ In the Reagan-Bush years, Justice Department lawyers worked on a self-styled Federalist

61. Compare Laurence H. Tribe, American Constitutional Law 816 (3d ed. 2000) (citing a combination of doctrines operating in the 1937-95 period that made "striking down a congressional attempt to invoke the commerce power as outside the affirmative scope of that power... a de facto impossibility"), with CHARles L. Black, JR., PERSPECTIVES IN CONSTITUTIONAL LAW 29 (1970) (arguing that a proper interpretation of the Commerce Clause would find judicially enforceable limits to the scope of the commerce power).

62. See TRIBE, supra note 61, at 819-22 (describing the Court's approach in Lopez as constituting a "new focus on 'economic' activity" the Court justified by a "post-hoc reconfiguration" of prior cases).

63. See infra notes 64-66 and accompanying text.

64. Douglas Kendall and Charles Lord describe conservative organizations' efforts to reshape the federal judiciary. Douglas T. Kendall \& Charles P. Lord, The Takings Project: A Critical Analysis and Assessment of the Progress So Far, 25 B.C. EnVTL. AfF. L. REV. 509, 530-49 (1998) (describing the judicial selection process and the role of the Federalist Society and other conservative legal organizations in the Reagan administration and beyond). Kendall and Lord focus on the Fifth Amendment's protections for private property. Conservatives also sought to alter Commerce Clause jurisprudence. See infra note 65. 
Project designed to bring about even bolder shifts in doctrine than the shift in Lopez. ${ }^{65}$

Such strategic activity is to be expected. As Professor Ackerman notes, "Really big constitutional changes do not generally occur in such a short time without lots of people setting their sights on some big ideas, and working hard and long to make them into realities (though, of course, the actual results may well fall short of activists' dreams). ${ }^{, 66}$ For purposes of the thought experiment, though, the existence of strategic players confounds the results. If strategic efforts to change the Court through appointments are properly considered in projecting doctrinal developments ten years hence, then the range of possibilities can expand considerably, and truly major doctrinal changes can fail to count as revolutionary or discontinuous transitions.

Ackerman might sidestep these complications in the present setting, because under his interpretation of the ten-year test, very few decades qualify as revolutionary. The changes that he recognizes as revolutionary - the Founding, Reconstruction, and the New Deal-all "inaugurate[d] ... sweeping transformation[s]." describes as a "root-and-branch repudiation of the leading precedents of the Lochner era." ${ }^{68}$ It amounted to more than just doctrinal change; it constituted a "self-conscious juridical reconstruction of framework values ... [ [which is] the hallmark of doctrinal revolutions." ${ }^{69}$ These are characterizations of legal upheaval that cannot be applied to many ten-year periods, and certainly not to our present circumstances (at least thus far).

Regardless of whether Ackerman would describe the recent federalism decisions as revolutionary, ${ }^{70}$ some observers might describe

65. Charles Fried, Order and Law: Arguing the Reagan Revolution-A FIRSTHAND ACCOUNT 182-88 (1991) (describing the efforts of Federalist Society members and others in the Reagan Justice Department to limit government power, including "[seeking] every possible way to redress the balance of power between the federal and local governments, which had shifted in the last half-century to favor the national government overwhelmingly").

66. Ackerman, supra note 50, at 2288.

67. 1 ACKERMAN, supra note 47 , at 77 .

68. Id.

69. Ackerman, supra note 50, at 2334.

70. Professor Ackerman has stated that the Rehnquist Court's recent federalism cases lie outside the evolutionary envelope fairly anticipated in 1990. E-mail from Bruce Ackerman, Sterling Professor of Law and Political Science, Yale Law School, to Christopher H. Schroeder, Professor of Law, Duke University School of Law (Aug. 24, 2001) (on file with the Duke Law Journal). 
them as such..$^{71}$ If this is a period of revolutionary change, however, it is also a period in which government actors have not marched down the four-step path to legitimacy. This is true even assuming for the sake of argument that the signaling and proposing steps in Ackerman's four-step process were achieved when the national Republican leadership embraced a conservative agenda in the 1994 Contract with America. ${ }^{72}$ Scholars have not seen anything approaching the kind of broad and sustained public deliberation over basic changes in our constitutional structure contemplated by the third step-mobilized public deliberation about the desirability of constitutional change. Candidates made practically no mention of the need for constitutional change in the 1994 election campaign, ${ }^{73}$ and surveys show that

71. An interesting indicator that the changes of the 1990 s were discontinuous with prior decisions is the fact that in 1999-2000 the Department of Justice notified the Congress twelve times that it could not defend the constitutionality of specific statutory provisions. Waxman, supra note 28, at 1086. The Solicitor General has a general obligation to defend any Act of Congress, and he or she will take the extreme step of not defending a statute only when he or she concludes that no respectable argument can be made on the statute's behalf. There is no question that the Department of Justice would have been prepared to defend each of these statutes in, say, 1991. There is no indication that Congress thought any of these laws to be so obviously unconstitutional when enacted that no plausible defense existed for them. The declination letters, then, seem to support the view that both the Executive and the Congress find the changes in constitutional doctrine to be discontinuous with the immediate past.

72. More than three hundred House candidates endorsed the Contract with America prior to the 1994 elections. See infra note 73. These candidates committed themselves to the Contract's ten-item platform, which the Republican leadership of the 104th Congress then pursued. Representative Bono summarized the Contract's terms:

No. 1, a balanced budget amendment and line-item veto;

No. 2, a new crime bill to stop violent criminals;

No. 3, welfare reform to encourage work, not dependence;

No. 4, family reinforcement to crack down on deadbeat dads and protect our children;

No. 5, tax cuts for families to lift Government's burden from middle-income Americans;

No. 6, national security restoration to protect our freedom;

No. 7, Senior Citizens' Equity Act to allow our seniors to work without Government penalty;

No. 8, Government regulation and unfunded mandate reforms;

No. 9, commonsense legal reform to end frivolous lawsuits; and

No. 10, Congressional term limits to make Congress a citizen legislature.

141 CONG. REC. 2476 (1995) (Statement of Rep. Bono (R-CA)).

73. The Contract with America was not silent on constitutional reform, but none of its proposals would have altered the Constitution's basic allocation of decisionmaking authority between the federal government and the states. As reflected in public opinion polling, the Contract's most popular proposal was a constitutional amendment that would have prohibited deficit spending. John B. Bader, The Contract with America: Origins and Assessments, in 
most Americans were completely unaware of the Contract with America on election day in $1994 .^{74}$

No shift in federalism doctrines has been fully codified, either. This last step in Ackerman's model requires a constitutional impasse followed by decisive and consolidating elections in which constitutional stakes play a significant role in electoral politics and in which the champions of revolutionary change prevail. ${ }^{75}$ Whatever the political climate in 1994, the elections of 1996 and 1998 failed to consolidate the most conservative components of the Republican agenda. ${ }^{76}$ The size of the Republican majority in the House was reduced in the elections of 1996 and 1998. ${ }^{77}$ The 1996 election in particular is more convincingly understood as a repudiation of Republican efforts to dismantle the federal government's regulatory apparatus than as an affirmation of those efforts. ${ }^{78}$ Ever since the 1996 election, Republicans have sought deregulatory objectives in less visible ways than the bold strokes of the Contract with America, thus taking Senator McCain's advice to trade in the "meat ax" for the "scalpel.", Con-

CONGRESS ReCOnSIDERED 347, 356 (Lawrence C. Dodd \& Bruce I. Oppenheimer eds., 6th ed. 1997). The second most popular proposal, which would have limited lawmakers' terms in office, also would have required a constitutional amendment. $I d$. No complaints against the existing constitutional structure as it relates to federalism were voiced in the Contract, and no constitutional amendments germane to federalism were proposed. The remaining items were popular policy initiatives - cutting taxes, strengthening the military, fighting crime, and so forth-that contemplated congressional action. Id. at 357 (presenting a table that identifies the Contract's goals and central issues). While devolution-enhancing measures were part of this package, the actions promised all could take place within the existing constitutional framework.

74. See, e.g., Editorial, End of the Beginning, L.A. DAILY NEWs, Apr. 10, 1995, available at 1995 WL 5399780 ("[I]f recent polls are to be believed, the bulk of the population doesn't even know of the contract's existence. And among those who know of it, approval of its provisions is far from unanimous.").

75. 1 ACKERMAN, supra note 47 , at 288-90.

76. Indeed, the elections in 1996, 1998, and 2000 have been so close that no consolidation currently exists around any political agenda. See, e.g., PAUL R. ABRAMSON ET AL., CHANGE AND CONTINUITY IN THE 1996 AND 1998 ELECTIONS 282 (1999) ("After the 1996 and 1998 elections there appeared to be no clear majority party in the United States ....").

77. The Republicans lost nine seats in the House of Representatives in the 1996 elections and another five seats in 1998. Id. at 191, 194.

78. See, e.g., Robert L. Glicksman \& Stephen B. Chapman, Regulatory Reform and (Breach of) the Contract with America: Improving Environmental Policy or Destroying Environmental Protection?, KAN. J.L. \& PUB. POL'Y, Winter 1996, at 9 (analyzing the reform proposals of Contract with America supporters as seen in their understanding of environmental regulation).

79. John McCain, Editorial, Nature Is Not a Liberal Plot, N.Y. TIMES, Nov. 22, 1996, at A31 (arguing that, by showing themselves "too eager to swing the meat ax of repeal when the scalpel of reform is what's needed," House Republicans, leading up to the 1996 elections, had succeeded in making their stewardship of the environment "the voters' number-one concern about continued Republican leadership of Congress"). 
gressional Republicans were nearly invisible on the national stage during the election, and George W. Bush's emphasis on "compassionate conservatism" prevented the narrow Republican victories of 2000 from being the kind of decisive election necessary to codify a revolutionary change. In any event, an election placing the loser of the popular vote in the White House hardly could be considered a consolidating election.

One interpretation of the past decade, then, would suggest that the nation has experienced revolutionary change without having experienced the procedural steps necessary to legitimate such change. If revolutionary constitutional change has occurred, and if that change is legitimate, one must conclude that as a descriptive matter Ackerman's model is incomplete. There must be a causal process at work that is materially different from the one Ackerman posits.

An alternative interpretation of the past decade is that the changes that have occurred are not revolutionary, but are nonetheless significant enough to have attracted considerable attention. Even under this more modest evaluation, one is left to wonder what has caused these changes at this point in the country's development.

Under either interpretation, then, something interesting has been taking place at the Supreme Court, and no one yet has offered a convincing explanation for it. The remainder of this Essay supplies a causal account of the changes that have occurred in the federalism cases.

\section{EXTERNAL AND INTERNAL EXPLANATIONS FOR LEGAL CHANGE}

The most obvious starting point for thinking about the causes of these legal changes is the shifting composition of the Court. In the last seventeen years a succession of appointments has replaced more liberal Justices with more conservative ones. Beginning in 1984, Antonin Scalia replaced Warren Burger, Anthony Kennedy replaced Lewis Powell, David Souter replaced William Brennan, and Clarence Thomas replaced Thurgood Marshall. ${ }^{80}$ As a result, the

80. President Bill Clinton's two appointees, Ruth Bader Ginsburg (replacing Byron White) and Stephen Breyer (replacing Harry Blackmun), were not radically more conservative than their predecessors. Breyer may be somewhat more conservative than Blackmun, but he and Ginsburg (who is more liberal than White) form part of the liberal wing of the current Court. Were their constitutional views to hold the majority, none of the revolutionary federalism rulings would have been made. 
Court has a more conservative center of gravity than it has in some time. ${ }^{81}$

These appointments were the product of a Republican strategy to stock the Court with conservatives. ${ }^{82}$ Some observers reject the idea that presidents will succeed in implementing judicial selection strategies. ${ }^{83}$ They can point to examples of presidents whose efforts to shape the Supreme Court's jurisprudence have been thwarted by the positions ultimately taken by their appointees. ${ }^{84}$ Notable instances of such surprises include President Dwight Eisenhower and Chief Justice Earl Warren, President Richard Nixon and Justice Harry Blackmun, and President George Bush and Justice David Souter. These surprises underscore a vision of a Court above politics by showing that presidents, even if they want to, cannot implement a political agenda through judicial appointments. Life tenure means that Justices will be their own people, and who those people will turn out to be is unpredictable. This claim of unpredictability contributes to the

81. But for the failure of Judge Robert Bork's nomination, the Court might be even more conservative. Without that defeat, the three Justices appointed after Scalia could well have been Robert Bork, Douglas Ginsburg, and Clarence Thomas. Judge Douglas Ginsburg of the Court of Appeals for the District of Columbia Circuit was nearly nominated to fill Justice Powell's seat after the Senate defeated Judge Bork's nomination to fill that vacancy. But Judge Ginsburg withdrew from consideration after stories arose of his past marijuana use while a law professor at Harvard. See Mark Gitenstein, Matters of Principle 312-16 (1992). Had Bork been confirmed, the intense media scrutiny of Ginsburg, which uncovered his marijuana use, would not have been as intense. Senator Orrin Hatch, a member of the Judiciary Committee at the time, thought that Ginsburg would have been confirmed even in the immediate aftermath of the Bork bitterness. The Reagan administration, however, was unwilling to risk a second defeat. After Ginsburg's withdrawal, Reagan nominated then-Judge Anthony Kennedy. Id. at 315-16. Conservatives within and outside of the Reagan administration thought Ginsburg was more conservative than Kennedy. Id. at 312-16.

82. See supra notes 64-66 and accompanying text.

83. See, e.g., Stephen B. Burbank, The Past and Present of Judicial Independence, 80 JUDICATURE 117, 119 (1996) ("[P]residents have so often been disappointed in their predictions ... [that] many take [this] as an important exhibit in the showcase of judicial independence."); Christopher E. Smith \& Thomas R. Hensley, Unfulfilled Aspirations: The Court-Packing Efforts of Presidents Reagan and Bush, 57 ALB. L. REV. 1111, 1113 (1994) (noting that the efforts of Presidents Reagan and Bush to "pack" the Supreme Court with conservatives fell short of policy objectives); Linda Greenhouse, Candid Look at High Court Finds that Presidents Can't Pack Bench, N.Y. TIMES, Oct. 20, 1984, at 1 (quoting Justice William Rehnquist's statement that, although presidents have the full right to pack the Court, presidents are likely to be disappointed by the votes and opinions of their nominees).

84. See, e.g., Marybeth Herald, Reversed, Vacated, and Split: The Supreme Court, the Ninth Circuit, and the Congress, 77 OR. L. REV. 405, 471 (1998) ("The history of the United States judiciary is replete with examples of judges appointed for life tenure whose decisions disappointed their appointing President.”). 
myth of the Court as a principled institution, a myth that many believe is a critical reason that the Court's decisions are respected. ${ }^{85}$

Life tenure does have a liberating effect on a Justice. But the fact that a Justice will have independence need not render his or her judicial philosophy completely inscrutable. Those who recommend judicial candidates for nomination frequently have enough evidence of a nominee's views to make reasonable estimates of his or her positions on key questions. They surely err from time to time, but a careful screening process can often develop a reasonably accurate picture of a person's outlook on broad questions of constitutional interpretation. The Court's results seldom prove entirely satisfying to purists because Court results require five votes, no one can predict individual voting patterns with complete accuracy, and no one can anticipate all the important issues that will come before the Court. The inability to achieve complete doctrinal satisfaction, however, is not a reason to abandon the attempt to move the Court, to the greatest possible extent, by strategic appointments. ${ }^{86}$ On big issues, about which the president and his appointments team care most deeply, the idea that nominees are unpredictable is more myth than reality. " $[\mathrm{I}] \mathrm{t}$ is undoubtedly true that the Supreme Court is susceptible to periodic political shifts due to its obvious connection to changes in political power ...." ${ }^{, 7}$

The connection between strategic appointments and the direction of the Court partly explains the constitutional shifts now under way. ${ }^{88}$ Yet stopping here would leave that explanation unsatisfactorily

85. Polling data suggest that, although the public thinks Supreme Court decisions are political, the public nonetheless has more respect for this branch of government than for the other two. See, e.g., Roger Handberg \& William S. Maddox, Public Support for the Supreme Court in the 1970s, 10 AM. POL. Q. 333, 337 (1982) (analyzing some explanations of public support for the Court based on national surveys conducted in 1972, 1974, and 1976 by the Center for Political Studies); Richard Lehne \& John Reynolds, The Impact of Judicial Activism on Public Opinion, 22 AM. J. POL. SCI. 896, 897 (1978) (using the Dolbeare-Hammond study on public support for the Court).

86. Judicial selection is influenced by other considerations in addition to ideology. This is an additional reason why a selection strategy will fall short of complete success. For example, diversifying the Court by adding individuals from racial or ethnic groups heretofore absent from the Court is an important consideration among Democrats and, to a degree, among Republicans. Friendships also weigh in the balance, although in recent years no president has appointed a confidant or friend.

87. Morton J. Horwitz, The Supreme Court, 1992 Term-Foreword: The Constitution of Change: Legal Fundamentality Without Fundamentalism, 107 HARV. L. REV. 30, 34 (1993).

88. See, e.g., Jack Balkin \& Sanford Levinson, Understanding the Constitutional Revolution, 87 VA. L. REV. 1045, 1066-83 (2001) (providing an extensive description of how a strategic ap- 
disconnected from the political and social changes outside the Court that in many respects parallel the doctrinal shifts on the inside. Despite the fact that the numbers of people identifying with liberal or conservative ideologies have not changed much, ${ }^{89}$ no one evaluating the energy and vitality of political ideologies in the United States today could miss the fact that in recent years conservative positions have had momentum and liberal positions have been on the defensive. ${ }^{90}$ Even the "L-word" itself has been thrown into disrepute. ${ }^{91}$ In many areas of public policy, conservative issues set the national agenda. From the issues of vouchers and choice in education, to the structure of the welfare state, to the need for a strong military despite the demise of the Soviet Union, to the concern over declining moral values, to the concern over the victims of reverse discrimination, conservatives have mounted substantial offensives. Liberals, on the other hand, cannot decide whether to persist in defending positions that seem more and more shopworn or to jump onto the still ill-defined "third way" bandwagon of the New Democrats.

Nowhere is the parallel between legal doctrine and political program more apparent than in the context of the federalism decisions and the devolution movement. Throughout the 1990s, the call for devolving more authority from the federal government to the states had enormous political appeal. The Unfunded Mandates Act, ${ }^{93}$ waivers of federal standards for state-initiated experiments in welfare programming, ${ }^{94}$ welfare reform that vests increased programmatic authority in

pointment strategy can result in "partisan entrenchment" if one party is able to make enough appointments to change the direction of the Court).

89. The National Election Studies measure of conservatism in the United States has stayed remarkably stable over the years, varying between fifty-one and fifty-four (on a scale of one hundred) between 1964 and 1998. The NES Guide to Public Opinion and Electoral Behavior: Conservatism Index 1964-1998, National Election Studies, available at http://www.umich.edu/ $\sim$ nes/nesguide/toptable/tab3_3.htm (Sept. 12, 2000) (on file with the Duke Law Journal).

90. David G. SAVAge, Turning Right 1-3 (1992).

91. Alan Ryan, Liberal Political Theory: Always Unpopular, IDEAs, No. 2, 2000, at 48.

92. For a discussion of the third way movement, see generally Christopher H. Schroeder, Third Way Environmentalism, 48 U. KAN. L. REV. 801 (2000).

93. Unfunded Mandates Reform Act of 1995, 2 U.S.C. § 1501 (Supp. V 1999).

94. See Michelle L. VanWiggeren, Comment, Experimenting with Block Grants and Temporary Assistance: The Attempt to Transform Welfare by Altering Federal-State Relations and Recipients' Due Process Rights, 46 EMORY L.J. 1327, 1333-36 (1997) (detailing the reemergence in the 1980s and 1990s of state authority in carrying out federal welfare programs, and stating that "as of 1996, forty-three states operated programs under at least one waiver"). 
the states, ${ }^{95}$ and the efforts by the Environmental Protection Agency to build federal-state partnerships for program design and implementation $^{96}$ all respond to the demand for devolution. In almost all policy areas, states are portrayed as the venues for creative and innovative solutions, and the federal government is the home of "one-size-fitsall" solutions that are inflexible and inappropriate by comparison. ${ }^{97}$

The Court's doctrinal shifts shaving back federal authority and affording more autonomy to state governments are judicial analogues to these administrative and legislative devolution initiatives. ${ }^{98}$ Any understanding of the Court as an institution embedded in society will require a deeper understanding of the connections between these parallel activities.

Externalists cast the connection in a direct and straightforward way. ${ }^{99}$ Externalism is the explanation for judicial decisionmaking that has dominated political science for the last forty years. It models judicial decisionmaking by assuming that Justices decide cases according to their personal preferences for outcomes. "[T]he Supreme Court decides disputes in light of the facts of the case vis-à-vis the ideological attitudes and values of the justices, $" 100$ and Justices regularly exercise their freedom "to base their decisions solely upon personal policy preferences." ${ }^{101}$ From an externalist viewpoint, presidents who favor devolution as a political preference appoint Justices who share that preference. Once confirmed, the Justices give life to those policies in their decisions.

Externalists can point to the "switch in time" as a particularly stark example of their model at work (although the switch itself was

95. Id. at 1335-51 (explaining the operation of the Personal Responsibility and Work Opportunity Reconciliation Act of 1996, and arguing that much of the shift of decisionmaking authority from federal to state governments already had occurred prior to its enactment).

96. See NAT'L ACAd. of Pub. Admin., Resolving the Paradox of EnVIronmental Protection: AN AgENDA For CONGRess, EPA, \& THE STATEs 46-52, 197-200 (1997) (summarizing the National Environmental Performance Partnership System, which was developed by the Environmental Protection Agency to share authority with the states).

97. Environmental regulation has been one policy area in which these characterizations are increasingly common. Id.

98. See infra notes $170-76$ and accompanying text.

99. See Laura Kalman, Law, Politics and the New Deal(s), 108 YALE. L.J. 2165, 2168-78 (1999) (using the terms "externalist" and "internalist").

100. Jeffrey A. Segal \& Harold J. Spaeth, The Supreme Court and the AtTitudinAl MODEL 65 (1993).

101. David W. Rohde \& Harold J. Spaeth, Supreme Court Decision Making 72 (1976) 
made by a sitting Justice) ${ }^{102}$ Faced with an assault on the institution of the Court itself-President Franklin D. Roosevelt's Court-packing plan and proposed constitutional amendments that would permit supermajorities of the House and Senate to overrule any Supreme Court decision-Justices Roberts and Hughes became more amenable to New Deal legislation. ${ }^{103}$ According to the externalist account, Justices Roberts and Hughes bowed to the political pressure made apparent by Roosevelt's reelection in $1936,{ }^{104}$ pressure that was brought to bear on the Justices by the then-circulating proposals to pack the Court or to amend the Constitution to weaken the Court's power of judicial review. ${ }^{105}$ President Roosevelt's strategic appointment of like-minded persons then reinforced the Court's newly found sympathy for New Deal programs. Nothing internal to the legal process prompted these changes; they can be explained only by invoking causal forces external to that process.

Externalist theories explain more recent doctrinal changes in a similar fashion. The shifting fortunes of the major political parties have been translated into the appointment of enough conservative Justices to change outcomes on the Court. To answer the question of

102. Owen Roberts was the Justice whose "switch in time" reversed the Court's approach to New Deal legislation, but the ascendancy of post-Lochner jurisprudence was secured only when President Roosevelt appointed Hugo Black, Stanley Reed, Felix Frankfurter, William O. Douglas, Frank Murphy, James F. Byrnes, Harlan F. Stone, Robert H. Jackson, and Wiley B. Rutledge to the Court. President Roosevelt's paramount criterion for selecting these Justices was fidelity to the tenets of what we now call post-Lochner jurisprudence. HENRY J. ABRAHAM, Justices AND Presidents: A POLITICAl History of APPOINTMENTS to THE Supreme COURT 209-10 (2d ed. 1985).

103. Justice Roberts's "conversion" first manifested itself when he joined a five-Justice majority in West Coast Hotel Co. v. Parrish, 300 U.S. 379 (1937) (upholding a state minimum wage law). Roberts subsequently joined identical five-Justice majorities in NLRB v. Jones \& Laughlin Steel Corp., 301 U.S. 1 (1937) (upholding the Wagner Act), Helvering v. Davis, 301 U.S. 619 (1937) (upholding the Social Security Act's "Federal Old-Age Benefits" provision), and Steward Machine Co. v. Davis, 301 U.S. 548 (1937) (upholding the Social Security Act's tax on employers).

104. See, e.g., Kalman, supra note 99, at 2169 ("Roberts and Hughes changed course abruptly in $1937 . .$. because of the threat posed by FDR's Court-packing plan."); William Lasser, The Supreme Court in Periods of Critical Realignment, 47 J. PoL. 1174, 1182 (1985) (stating that after the 1936 election, "the Court succumbed to the verdict of the people").

105. Michael Ariens, A Thrice-Told Tale, or Felix the Cat, 107 HARV. L. REV. 620, 631 (1994) ("[F]or more than a decade and a half, most studies of the constitutional crisis of 1937 concluded that politics, in the form of FDR's reelection and his Court reorganization plan, caused the Court to alter its voting pattern."). 
why those fortunes have shifted, one must look to theories of political change, such as critical election or punctuated equilibria theory. ${ }^{106}$

The legal profession is more familiar with internalist explanations of judicial decisionmaking than with externalist explanations. In contrast to the externalist approach, the internalist approach posits that Justices decide cases based on their good faith efforts to apply legal reasoning to the existing body of authoritative materials. ${ }^{107} \mathrm{Ad}-$ herents of internalism challenge externalism by engaging in close analysis of cases to see whether they are consistent with precedent and sound legal reasoning ${ }^{108}$ or by touting examples of cases decided against the presumed preferences of the judges. ${ }^{109}$ Some internalists do not even concede the "switch in time" to the externalists. Scholars such as Barry Cushman and Richard Friedman, ${ }^{110}$ for example, "emphasize the plausible internal and intellectual reasons for the Court's journey" in the 1930s, by "point[ing] to doctrinal changes that began before 1937 and continued thereafter." 111 In explaining the recent shifts in Supreme Court doctrine, internalism would strive to demon-

106. On critical elections, see THE END OF REALIGNMENT? INTERPRETING AMERICAN ELECTORAL ERAS (Byron E. Shafer ed., 1991) (containing essays describing and debating critical election theory). On punctuated equilibria, see FRANK R. BAUMGARTNER \& BRYAN D. Jones, Agendas and Instability in AMerican Politics 3-24 (1993) (describing punctuated equilibria in American policy and politics), and Walter Dean Burnham, Constitutional Moments and Punctuated Equilibria: A Political Scientist Confronts Bruce Ackerman's We the People, 108 YALE L.J. 2237, 2249-61 (1999) (applying the theory of punctuated equilibria to constitutional change). See also Keith E. Whittington, Taking What They Give Us: Explaining the Court's Federalism Offensive, 51 DUKE L.J. 477, 477, 480-86 (2001) (describing different theories of political change).

107. See, e.g., Frank B. Cross, Political Science and the New Legal Realism: A Case of Unfortunate Interdisciplinary Ignorance, 92 Nw. U. L. REV. 251, 255 (1997) ("The classic legal model [internalism] suggests that the path of the law can be identified through reasoned analysis of factors internal to the law."). Cross's article is an excellent review and analysis of existing research on the externalist model, as well as the tensions between internalism and externalism. Internalists concede that judges can on occasion give expression to their own policy preferences, but they insist that decisions based on reasoned analysis of factors internal to the law are possible and that they predominate in judicial decisionmaking.

108. See, e.g., Kalman, supra note 99, at 2174-78 (summarizing how internalists attempt to link pre-1937 and post-1937 cases through normal techniques of judicial reasoning); Pepper, supra note 56 , at $70-81$ (same).

109. See infra note 112 .

110. See supra note 55 and accompanying text.

111. Kalman, supra note 99, at 2169. Internalist interpretations of the events of 1937 are not new. Such interpretations had advocates in the immediate aftermath. See Ariens, supra note 105, at 630 (pointing to Merlo J. Pusey, THE Supreme Court Crisis (1937), as an early example). 
strate that recent decisions can be justified by applying standard precepts of legal reasoning to existing legal materials.

Both internalism and externalism have characteristic strengths and weaknesses in explaining legal change. By invoking facts external to the process of legal reasoning, externalists treat new appointments to the Court as a shock to the judicial system that upsets the prior distribution of votes on the Court, causing a new configuration of policy preferences to comprise the majority. By stressing outside factors, externalism takes advantage of the obvious. Externalism's weakness is that it does a disservice to the phenomenology of judging. Judges regularly report that they experience law as constraining. ${ }^{112}$ People typically describe themselves as pursuing their preferences willingly, not as doing so reluctantly or under duress. To cope with the apparent fact that law is experienced as constraining, the externalist position must assert either that (a) judges are deluding themselves about what they are doing; or (b) judges are dissembling when they explain what they are doing. ${ }^{113}$ Both positions lie beyond the ability of externalists to verify, and both prove unsatisfying, even to those judicial observers prepared to concede that judges on occasion reach decisions based on policy preferences.

Internalism respects the feelings of judges and lawyers who report that they feel constrained by the law. Its greatest difficulty lies in developing a coherent explanation for the kind of legal change represented by the recent federalism decisions-changes that, whether revolutionary or not, depart significantly from the cases that preceded them. By emphasizing that law develops incrementally through application of legal reasoning to existing legal materials, internalism suggests that new decisions necessarily will be continuous with the old. So how does sharp change occur? Two explanations are possible. On the one hand, the new direction can be interpreted as a correction of

112. See, e.g., CUSHMAN, supra note 55, at 41 (insisting that law is largely autonomous from politics and that it cannot be reduced "to the status of dependent variable ... [because doing so would] deny that judges deciding cases experience legal ideas as constraints on their own political preferences"); Alvin B. Rubin, Does Law Matter? A Judge's Response to the Critical Legal Studies Movement, 37 J. LEGAL EDUC. 307, 307-08 (1987) (claiming based on his experience as a judge that "legal doctrine is a real force, judges follow it, and they decide all but a small fraction of the cases that come before them in accordance with what they perceive to be the controlling legal rules").

113. See Anthony D'Amato, Aspects of Deconstruction: Refuting Indeterminacy with One Bold Thought, 85 Nw. U. L. REV. 113, 118 (1990) (noting that externalists think that "justificatory legal language .... is a mode of couching the personal legislative preferences of unelected judges in the publicly venerated language of a judicial decree"). 
error. For example, an internalist may argue that constitutional change occurs when the Court abandons erroneous recent decisions for earlier correct ones. A "restorationist" story of this kind is popular among lawyers who favor originalism. ${ }^{114}$ The second explanation already has been suggested. Internalists may dispute the premise that the Court has departed from precedent. By engaging in (what they claim is) a more sophisticated analysis of the legal materials, internalists of this stripe attempt to show that what has been described as a shift actually is continuous with prior interpretations. ${ }^{115}$

There are serious problems with either internalist explanation. The restorationist approach can explain at best only constitutional changes that move in the direction from error to reason. But for every one of these enlightened moves there must have been a prior move from reason to error. This approach lacks any theory to explain why error was made in the first place. The revisionist approach, on the other hand, fails to provide a convincing account of why, among the possible routes legal development might have taken, a particular one was chosen. When dealing with significant changes in doctrine, there always will be a more straightforward course of doctrinal development that could have been chosen-it is the deviation from that course that prompts the need for a deeper revisionist explanation. For example, even after the erudite and close revisionist analyses of Cushman, Friedman, and others, the most that has been shown is that the post-1937 decisions are more consistent with prior decisions than was commonly supposed. These analyses cannot demonstrate that the post-1937 decisions were compelled by prior decisions according to the normal methods of judicial reasoning. ${ }^{116}$ Whenever more than one outcome is consistent with prior decisions, revisionism cannot explain why the Court chose one path rather than another.

\footnotetext{
114. See Stephen M. Griffin, Constitutional Theory Transformed, 108 YALE L.J. 2115, 2117 (1999) (describing "the best known, most widely accepted, and most implausible account of constitutional change during the New Deal-that it involved no real change as such, but was simply a restoration of the previous wisdom of the Marshall Court"). Bruce Ackerman refers to this approach as "the myth of rediscovery." 1 ACKERMAN, supra note 47, at 43.

115. See supra notes $108-11$ and accompanying text.

116. Revisionists rely upon a handful of pre-1937 decisions as laying the jurisprudential groundwork for 1937 cases such as West Coast Hotel and Jones \& Laughlin. The best evidence that the earlier decisions did not compel those 1937 results comes from lower court decisions from the 1930s. Lower courts did not read the pre-1937 cases as compelling the results of 1937. Pepper, supra note 56, at 100-03,112-14. The scholarly community at the time also did not find that the pre-1937 cases logically compelled the 1937 results. E.g., id. at 120 ("To most [liberal] scholars ... the promise of Nebbia was a distant memory [by 1936] ....”).
} 
The weaknesses of the internal and external approaches indicate that neither model, standing alone, is sufficient to explain judicial decisionmaking. This should compel observers to look beyond these two traditional approaches for an adequate explanation of doctrinal change. Ackerman's theory of constitutional moments is one alternative to purely internalist or externalist explanations. It identifies the four-step procedure characterized by institutional impasse and popular mobilization -instead of the enshrinement of an individual judge's policy preferences or the conscientious application of legal reasoning to existing legal authorities-as codifying the successful revolutionary impulse. Once codified, these new revolutionary values are incorporated into the body of texts available to judges as they approach subsequent disputes. A judge's subsequent elaboration of these constitutional changes then can be explained through internal modeling. Ackerman's theory thus takes advantage of the externalist insight that significant legal change usually results from shocks external to the system as well as the internalist insight that judges approach their job with a professional commitment to the relative autonomy of the law. The bridge between these externalist and internalist insightsthe most controversial feature of the theory-is Ackerman's constitutional moment, in which those external shocks are translated into legitimate legal texts to which the tools of legal reasoning can be applied. $^{117}$

Yet Ackerman's theory of how the gap between the external and the internal is bridged does not explain the Court's recent federalism jurisprudence. Conspicuously absent are the laborious public and political processes that would explain the recent federalism changes as a constitutional moment. Despite the inapplicability of Ackerman's ap-

117. 1 ACKERMAN, supra note 47, at 60-61. Ackerman emphasizes that judges can and do actually decide cases according to law, while adding the important thought that the legal materials judges use can be legitimately affected by events external to the Court's jurisprudence.

Does it even make sense to think of "constitutional interpretation" as a disciplined activity with its own criteria of good and bad arguments, its own claim to integrity? Or is it just a mystifying shell game that conceals each participant's ordinary political commitments? These questions are absolutely critical to your assessment of [my interpretive] enterprise .... Despite the difficulties, courts have in fact devised a rough-and-ready way to sustain the values of constitutional politics against erosion by normal politics. This conclusion will be of special importance to the professionals charged with keeping the machine in good working order.

Id. In my view, Ackerman's position is therefore not simply another externalist one, although that is how he has sometimes been interpreted. See, e.g., Kalman, supra note 99, at 2170 ("I read Ackerman to embrace the externalist position."). 
proach, his underlying desire to combine what is sound in each of the internalist and externalist models ought to inform any attempt to understand the Court's recent federalism decisions.

The remainder of this Essay advances a thesis about judicial change that bridges the gap between externalism and internalism in a way that overcomes the weaknesses of each. The account is externalist in arguing that the dynamics of constitutional change can be understood only by recognizing that the Supreme Court is embedded in society, and that the events and social forces that affect public opinion, intellectuals, and others also influence the judiciary. It is internalist as well, for it endorses a version of the view that judges take doctrine and techniques of legal reasoning seriously. It explains that judges' responses to social forces are shaped by the doctrinal lens through which they must be filtered. The social, intellectual, and economic movements that lie behind conservative political successes also condition judges' thought processes with respect to the kinds of arguments they find persuasive. ${ }^{118}$

\section{Constitutional Law As the Allocation of DECISIONMAKING AUTHORITY}

An account of the ways in which social, political, and cultural influences affect constitutional decisions must begin with an explanation of the basic function constitutional decisions perform. When the Court renders a constitutional decision, it is deciding the proper allocation of decisionmaking power. Even decisions protecting individual rights almost always protect rights to make decisions. ${ }^{119}$ Many of the rights the Bill of Rights protects-the right to free speech, ${ }^{120}$ to practice religion, ${ }^{121}$ to bear arms, ${ }^{122}$ to a jury trial in criminal prosecu-

118. This argument does not claim to constitute a general theory of the interaction between social, economic, and intellectual contexts on the one hand and judicial doctrine on the other, although the approach it develops may apply in other doctrinal areas.

119. The exceptions are rights protected by an inalienability rule, such as the Thirteenth Amendment right not to be enslaved. See Guido Calabresi \& A. Douglas Melamed, Property Rules, Liability Rules, and Inalienability: One View of the Cathedral, 85 HARV. L. REV. 1089, 1092-93 (1972) (describing rights protected by liability rules, property rules, and inalienability rules); see also Madeline Morris, The Structure of Entitlements, 78 CORNELL L. REV. 822, 82425 (1993) (summarizing Calabresi and Melamed's different forms of entitlement).

120. U.S. CONST. amend. I.

121. Id.

122. U.S. CONST. amend. II. 
tions, ${ }^{123}$ and so on-are grants of decisionmaking power to the individual as opposed to the government. Because an individual can decline to exercise any of these rights, or can waive them, a constitutional decision in her favor empowers her to make the decision whether to bear arms, practice religion, speak freely, be tried by a jury, and so on.

Federalism doctrines allocate decisionmaking authority even more obviously. These doctrines often are referred to as the structural part of the Constitution because they allocate authority among branches of government. When a federalism doctrine prevents Congress from compelling state performance (to implement a prepurchase background check for handguns, to submit to jurisdiction in federal or state court, or to carve religious exceptions out of laws of general application, for example), the federalism barrier vests the state with the autonomous power to decide whether to cooperate with the federal plan. Either the federal government or the state government is allocated the power to make this choice. The constitutional decision determines the allocation. ${ }^{124}$

Internalists posit that constitutional text, history, purpose, and legal reasoning provide answers to the question of how power ought to be allocated. Externalists posit that judges, like the rest of us, have preferences with respect to who holds power-a claim that internalists do not deny (although they deny that those preferences are controlling) — and that these preferences control legal decisions.

In claiming a quasi-independent status for legal reasoning, internalists must confront the fact that there is a good deal of empirical support for the theory propounded by the externalists. Study after study has shown a significant correlation between various measures of Justices' policy preferences and their votes. ${ }^{125}$ Is there an account of legal reasoning that maintains the quasi-independent character of legal reasoning while also explaining why judicial decisions frequently follow judicial preferences?

123. U.S. CONST. amend. VI.

124. Before the Court decides a constitutional claim that allocates decisionmaking authority, it inevitably faces a threshold power allocation question. The Court must consider several justiciability and jurisdictional doctrines-such as subject matter jurisdiction, in personam jurisdiction, standing, ripeness, and the political question doctrine-to determine whether the Court will make the underlying power-allocating decision or whether the Court will accede to the determination of other branches of government.

125. See Cross, supra note 107, at 277-78 (discussing several studies by political scientists that show ideological decisionmaking by judges). 
The following Part develops a theory of how people acquire preferences about the allocation of government decisionmaking authority. It argues that a crucial issue in acquiring these preferences is trust, an attitude dependent upon three key criteria that are historically and socially contingent. Within the last thirty years, trust in federal institutions has declined, and historical and social conditions go a long way toward explaining why federal solutions to policy problems are less attractive today compared to state, local, or individual solutions. ${ }^{126}$ Part $\mathrm{V}$ then describes research in the cognitive sciences suggesting that attitudes about the trustworthiness of the federal government might have an internal effect on the persuasiveness of certain arguments related to the allocation of decisionmaking authority.

\section{TRUST IN GOVERNMENT}

Trust is a more complicated concept than many people assume. Trust can be specific (e.g., I trust my garage mechanic to fix my car), or trust can be general (e.g., I trust my sister to raise her children well). ${ }^{127}$ The decision to trust another person turns on three considerations. First, my decision to trust someone depends on whether I believe that in executing whatever responsibilities I give her, the other will act to further my desires or interests. This belief could arise because of incentives created by the relationship, such as my agreeing to pay a mechanic only for a successful repair job. Incentives also could be created because of the anticipation of future interactions. Even if I am unable to judge the quality of a repair job when I pick up my car, I have a choice whether to return to that mechanic. If my experience driving the car later reveals a shoddy repair, I may not return, and I also may advise others to go elsewhere for their repairs.

126. This Essay was written before terrorists attacked the World Trade Center in New York and the Pentagon on September 11, 2001. There are early indications that in the aftermath of these events, confidence in the federal government has become stronger than at any time in the past thirty years. See infra note 191. This revival of trust in the federal government, even if it proves to be of more than transitory duration, would not detract from this Essay's main point that the level of trust in a government body affects the amount of decisionmaking power it is allocated. Consistent with this Essay's analysis, the revival of trust caused by the terrorist attacks could affect the future direction of federalism decisions. For further discussion of the aftermath of the events of September 11, 2001, on the course of federalism doctrine, see infra notes 191, 202, and 232.

127. Russell Hardin, Trust in Government, in TRUST AND Governance 9, 12 (Valerie Braithwaite \& Margaret Levi eds., 1998). 
Russell Hardin has called this aspect of trust "encapsulated interest." ${ }^{128}$ He writes that

I can ... say I trust you with respect to some action if your reason for doing it is to take me into account in some relevant way. Typically your reason will be that it is in your interest to maintain our relationship. Hence, my trust in you is typically encapsulated in your interest in fulfilling my trust. ${ }^{129}$

Besides being maintained by the incentives that are part of a relationship, trust also could be maintained by the belief that the other person shares my beliefs and preferences. If that is so, my interests will be taken into account simply by virtue of the other person acting according to her interests. Because the Antifederalists thought such shared interest was essential to the representational process in government, they insisted that any legislative body be a "miniature" or "exact portrait" of the people as a whole. ${ }^{130}$ More recently, William Bianco has argued that the belief that an elected representative shares "common interests" with voters is an important factor in voters' decisions to trust those representatives. ${ }^{131}$

A second consideration affecting trust is competence. I will be more prepared to trust the garage mechanic to fix my car properly if I believe he has the skills to do so. Competence includes elements of knowledge, training, and intellect. Interest groups and elites play an indispensable societal role by providing signals and cues to usually less well-informed citizens regarding the merits of government policies. They could not do so if citizens did not believe they were capable of evaluating policy consequences correctly. ${ }^{132}$

Finally, the decision to trust depends upon the costs of declining to do so. The greater the disparity between the consequences of trusting or not, the more likely a person is to invest trust. I may doubt the competence of a mechanic, but if the consequence of not having

\footnotetext{
128. Id. at 12 .

129. Id.

130. See Jack N. Rakove, Original Meanings: Politics and Ideas in the Making OF THE CONSTitution, 203, 234-43 (1996) (summarizing Antifederalist complaints that the Constitution made Congress too small to provide an exact portrait of the American people).

131. William Bianco, Trust 45 (1994).

132. See Arthur lupia \& Mathew D. McCubbins, The Democratic Dilemma 61 (1998) ("[A] speaker's statements can persuade an observer when the observer believes the speaker to be knowledgeable and truthful in what he says ....”).
} 
him repair my car is that I will be late for a job interview in the next town, I likely will take the chance. ${ }^{133}$

The nation's declining willingness to give decisionmaking authority to the federal government ${ }^{134}$ is attributable to the federal government's poor performance during the last thirty-five years with respect to all three of these components of trust. ${ }^{135}$

\section{A. Encapsulated Interest}

Americans increasingly believe that national representatives do not have their interests in mind when making decisions in Washington. Citizens believe that the self-interest of politicians is aligned with concentrated interest groups and moneyed interests that provide benefits to politicians both during office and after.

By a $74 \%$ to $17 \%$ margin, Americans think members of Congress work on making themselves look better rather than on making the country better. ${ }^{136}$ By a $61 \%$ to $32 \%$ margin, people think it is impossible for members of Congress to avoid being influenced in their policymaking decisions by the financial contributions that they receive. ${ }^{137}$ Accordingly, people believe that congressional decisionmaking is dominated by special interests that can contribute to campaigns in amounts that individuals cannot match. When asked about the power of different groups over national policymaking, $79 \%$ to $88 \%$ of people responded that "big companies," "political parties," the "news media," and "political lobbyists" all exert too much influence. ${ }^{138}$ Top-

133. Perhaps the decision to hire the mechanic does not result from trust, but instead results from a reluctant acceptance of the necessity of giving him the job. The three factors of encapsulated interest, competence, and costs are all germane to the power allocation decisions central to this Essay, regardless of whether the dependent variable they affect is labeled a decision to trust or a decision to invest responsibility.

134. For evidence of this decline, see infra notes $144-55$ and accompanying text.

135. These three variables may not be completely independent. For instance, Tom Tyler's research suggests that the "benevolence of the motives of the authority" - a characteristic similar to encapsulated interest-affects one's judgment that the authority is competent and honest. Tom R. Tyler, Trust and Democratic Governance, in TRUST AND GOVERNANCE, supra note 127, at 269-70, 273. The extent of their interdependence does not affect the present analysis.

136. Capitol Hill Watch: Congressional Facts and Figures, 29 NAT’L J. 524, 524 (1997) (citing a poll by Opinion Dynamics for Fox News, conducted on February 19-20, 1997).

137. Id.

138. Louis Harris and Associates Poll of Nov. 8, 1994, Roper Center for Public Opinion Research, at http://web.lexis-nexis.com/universe (last visited Oct. 7, 2001) (accession number 0224610) (on file with the Duke Law Journal) (observing that $86 \%$ of those surveyed believed that big companies have too much influence in Washington); Louis Harris and Associates Poll of Nov. 8, 1994, Roper Center for Public Opinion Research, at http://web.lexis-nexis.com/ 
ping the list of groups with too much influence are "PACS who give money to political candidates" $-88 \%$ thought they exert too much influence. ${ }^{139}$ What is more, Americans differentiate sharply between special interests and the interests of ordinary Americans such as themselves. Eighty-two percent polled in 1992 felt that "those we elect to Congress in Washington lose touch with the people pretty quickly." ${ }^{, 140}$ Only $16 \%$ disagreed. ${ }^{141}$ The conviction that members of Congress look out for themselves and for the special interests, but not for the average citizen, produces very low confidence in the institution. Overall, only 11\% of those responding in 1997 expressed "a great deal of confidence" in Congress. ${ }^{142}$

A remark made by a citizen to the Washington Post summarizes the public's overall disposition toward Congress: “'Unfortunately I think that... there are so many special-interest groups that have bucks, and [members of Congress] are going to work on taking care of them. The people that make the most noise get the most attention,

universe (last visited Oct. 7, 2001) (accession number 0224611) (on file with the Duke Law Journal) (observing that $80 \%$ of those surveyed believed that political parties have too much influence in Washington); Louis Harris and Associates Poll of Nov. 8, 1994, Roper Center for Public Opinion Research, at http://web.lexis-nexis.com/universe (last visited Oct. 7, 2001) (accession number 0224612) (on file with the Duke Law Journal) (observing that $79 \%$ of those surveyed believed that the news media have too much influence in Washington); Louis Harris and Associates Poll of Nov. 8, 1994, Roper Center for Public Opinion Research, at http://web.lexisnexis.com/universe (last visited Oct. 7, 2001) (accession number 0224613) (on file with the Duke Law Journal) (observing that $79 \%$ of those surveyed believed that political lobbyists have too much influence in Washington).

139. Louis Harris and Associates Poll of Nov. 8, 1994, Roper Center for Public Opinion Research, at http://web.lexis-nexis.com/universe (last visited Oct. 7, 2001) (accession number 0224609) (on file with the Duke Law Journal).

140. Cong. Research Serv., Public Opinion of Congress and Its Members 13, tbl.5 (1993) (citing an ABC News Poll of Apr. 8-9, 1992). John Hibbing and Elizabeth Theiss-Morse report the same general findings-that $86 \%$ of respondents stated that special interest groups exert too much influence—and the same disjunction between "special interests" and the general population:

Whereas close observers of politics are likely to see interest groups as vital links between the public and the government, helping to capture and to express the diversity of the public's views, the people themselves see the situation quite differently. Interest groups, they contend, are definitely not connected with ordinary people, even remotely. Instead, the popular notion is that these special interests are completely divorced from the public interest.

John Hibbing \& Elizabeth Theiss-Morse, Congress As the Public Enemy 63-64 (1995).

141. Cong. ReSEARCH Serv., supra note 140, at 13, tbl.5 (1993) (citing an ABC News Poll of April 8-9, 1992).

142. Louis Harris \& Associates Poll, NAT'L L.J., Mar. 10, 1997, at A5. 
and those people have the money and the numbers to get it." ${ }^{\prime 143}$ The sentiment this remark encapsulates is the opposite of trust.

\section{B. Competence}

People learn about the government's competence from experience with prior government efforts to undertake significant tasks. In the past thirty years, such undertakings have been studded with failures. We might mark the onset of the Cynical Era with President Lyndon B. Johnson's campaign pledge that "no American boy will fight a foreign war on a foreign soil if I'm elected president." ${ }^{144}$ Within a year of that remark, President Johnson dramatically increased draft calls and began a massive buildup of American soldiers in Vietnam. ${ }^{145}$ For some, the Vietnam War was one of the federal government's most notable failures because the government refused to prosecute the war to a successful conclusion; for others, it was a failure because of the government's decision to enter the war in the first place. The Vietnam War shook citizens' confidence in the competence of the federal government. ${ }^{146}$

Around the time of President Johnson's reversal, polls measuring trust or confidence in government showed a steep decline, a decline from which confidence levels have not recovered. ${ }^{147}$ Subsequent events did not bring about a recovery of confidence: Watergate came on the heels of the Vietnam War, and both President Nixon's duplicity and President Ford's subsequent unpopular pardon of Nixon cemented the public's distrust of Washington.

The 1970s also brought the energy crisis, as well as severe inflation and high interest rates, undermining confidence in the federal government's ability to control critical elements of the nation's economic life-elements that Keynesians and others had assured the public could be managed. Toward the end of the decade, President Carter became ensnared by the Iranian hostage crisis, which many

143. HIBBING \& THEISS-MORSE, supra note 140, at 65 .

144. John H. Aldrich, Why Parties? The Origin AND Transformation of POLITICAL PARTIES IN AMERICA 194 (1995).

145. See generally CIA Warned LBJ in '65 that Vietnam War Would Fail, SALT LAKE TRIB., Mar. 30, 1994, at A9 (discussing the Central Intelligence Agency's warning to President Johnson prior to the 1965 troop buildup that the Vietnam War could not be won).

146. President Johnson's inconsistent words and actions also undermined the first dimension of trust, encapsulated interest.

147. HibBING \& THEISS-MoRse, supra note 140, at 33. 
people thought he handled ineptly. ${ }^{148}$ Violent crime surged. Faith in the national government was hammered by these events. "The energy shortages ... suggested that government could not protect America's reliance on cheap, plentiful energy. The Iran hostage standoff... suggested the mighty American government could not protect its citizens abroad. And the surge in violent crime ... suggested government could not even protect its citizens at home."149 Consequently, when President Reagan began the 1980s by announcing in his inaugural address that "government is not the solution to our problem," his words ratified and legitimized an already widespread opinion. ${ }^{150}$

Then came years of mounting budget deficits. ${ }^{151}$ Although federal officials equivocated early on, ${ }^{152}$ leaders of both parties eventually endorsed the thesis that deficits were irresponsible public policy and needed to be eliminated. ${ }^{153}$ Despite its plenary power of the purse,

148. See, e.g., Stephen Craig, The Malevolent Leaders: Popular Discontent in AMERICA 2-3 (1993) (attributing the "strained relationship between citizens and their leaders" to the fact that "[g]overnment in general, and the national government in particular, simply has not done a very good job of dealing with the country's most important problems," and then enumerating a list of similar failures).

149. CNN Inside Politics (CNN television broadcast, Aug. 20, 2001) (transcript on file with the Duke Law Journal).

150. Ronald Reagan, Inaugural Address, Jan. 20, 1981, in PUblic PAPERS OF THE PRESIDENTS OF THE UNited StATES: RonAld REAGAN, 1981, at 1 (1982).

151. Except for the 1969 fiscal year, the federal budget was in deficit every year from 1961 to 1997, but in relatively modest amounts until 1983, when the combined effects of the 1981 Reagan tax cut and a recession put the deficit over $\$ 100$ billion for the first time. It reached a high of $\$ 290$ billion in 1992, and remained constant around $\$ 100$ billion for thirteen consecutive years. Budget of the United States Government for Fiscal Year 2002, Historical Tables, United States Office of Management and Budget, available at http://wais.access.gpo.gov (Aug. 11, 2001) (on file with the Duke Law Journal).

152. See, e.g., A Month After the Tax Cut, a Tax Hike, 13 NAT'L J. 1714, 1715 (1981) (citing Council of Economic Advisors Chairman Murray Weidenbaum's statement that the Reagan administration was unconcerned about revenue loss that resulted from major tax cuts the year before).

153. In 1985, one of the first major legislative efforts to reduce the budget deficit was cosponsored by two Republicans and one Democrat. See Bowsher v. Synar, 478 U.S. 714, 717 (1986) (noting that the Balanced Budget and Emergency Deficit Control Act of 1985, Pub. L. 99-177, 99 Stat. 1038 (codified at 2 U.S.C. $\S \S 901-22$ (1994)), was also known as the "GrammRudman-Hollings Act," named after Rep. Phil Gramm (R-TX), Senator Warren Rudman (RNH), and Senator Fritz Hollings (D-SC)). In 1987, the Congress established a bipartisan National Economic Commission, composed of six Republicans and six Democrats, to propose solutions to the budget deficit. See, e.g., Bob Woodward, No-Tax Vow Scuttled Anti-Deficit Mission, WASH. Post, Oct. 5, 1992, at A1 (asserting that the purpose of the NEC was to determine "a way to eliminate the federal red ink that most economists believed was damaging the economy"). By 1990, Republican President George H.W. Bush had come to think the budget deficit was such a significant domestic problem that he broke his "no new taxes" pledge to the Republican Convention in 1988 in order to support a bipartisan budget deficit plan that included tax 
Congress seemed incapable of balancing the budget, until it was rescued by a combination of devolutionary fiscal policy and a booming economy.

The nearly two decades of budget deficits provide a stunning example of a category of public problems in which Congress is unable to satisfy the public's expectations. This "bound-to-fail" category includes problems everyone agrees should be fixed, and that could be fixed by any of several methods, none of which commands a political consensus. ${ }^{154}$ Examples include maintaining a strong economy, reducing violent crime, and eliminating the deficit. When Congress fails to act, or is perceived as taking only weak or partial measures, people

increases. E.g., Susan Page, Read-His-Lips Reversal; Bush Concedes Tax Hikes are Needed to Offset Deficit, NewSDAY, June 27, 1990, at 3 (quoting President Bush):

It is clear to me that both the size of the deficit problem and the need for a package that can be enacted require all of the following: Entitlement and mandatory program reform; tax revenue increases; growth incentives; discretionary spending reductions; orderly reductions in defense expenditures; and budget process reform. ... The bipartisan congressional leadership agree with me on these points.

Breaking that pledge may have cost President Bush his 1992 reelection. President Clinton later claimed credit for reducing the budget deficit in his 1994 State of the Union Address. See President William Jefferson Clinton, State of the Union Address delivered before the Joint Session of Congress (Jan. 26, 1994) ("Last year, we began to put our house in order by tackling the budget deficit that [is] driving us toward bankruptcy."). The budget deficit had been a major campaign issue in the 1992 race between Bush, Clinton and third-party candidate Ross Perot, who insisted that the major parties were ducking the hard choices necessary to solve the problem. See, e.g., Steven Mufson, Politicians Wavering on Debt Crisis Issue; Candidates Fall Far Short on Solutions, WASH. Post, Sept. 29, 1992, at A1 (describing Perot's insistence that the major parties were avoiding putting forth realistic plans to address the problem of the national debt, which Perot described as "like a crazy aunt we keep down in the basement. All the neighbors know she's there, but nobody wants to talk about her."). It was during that campaign cycle that former Republican Senator Warren Rudman and former Democratic Senator (and former candidate for the Democratic presidential nomination in 1992) Paul Tsongas formed the Concord Coalition, aimed at keeping both parties' feet to the fire with regard to bringing down the budget deficit. See, e.g., David S. Broder, Forcing the Candidates to Face Reality; Tsongas and Rudman Hope to Extract More Honesty about the Deficit from Clinton and Bush, WASH. POST, July 26, 1992, at C7 (describing the agenda of the Concord Coalition).

154. See HibiIng \& THEISS-MORSE, supra note 140, at 53-56 (referring to the public's reaction in such situations as "valence dissatisfaction"); Lawrence C. Dodd, Congress and the Politics of Renewal: Redressing the Crisis of Legitimation, in CONGRESS RECONSIDERED 417, 41819 (Lawrence C. Dodd \& Bruce I. Oppenheimer eds., 5thed. 1993):

$[\mathrm{T}] \mathrm{o}$ sustain the long-term support of the public, Congress and its members must demonstrate a reasonable capacity to recognize the fundamental problems of a historical era, deliberate over the proper solutions to these problems, and enact legislation that addresses them in a credible manner. The public does not expect miracles from Congress .... But the public does look to Congress to grapple with the serious issues of the day and to fashion reasonable strategies for addressing them. 
who disagree bitterly as to what Congress should do unite in their dissatisfaction with Congress having done nothing. ${ }^{155}$

Such inaction stems in large part from the system of checks and balances built into the Constitution, but the public's adverse reaction to the resulting immobility redounds to the federal government's detriment. Congress often is seen as the recalcitrant partner blocking presidential initiatives. ${ }^{156}$ The president often is seen as the positive, affirmative political actor, proposing programs, advancing an agenda, and urging change. Congress has tremendous difficulty speaking affirmatively because it speaks with many voices, thus projecting a diffuse image. The overall impression is that the institution has no coherent proposals for responding constructively to the country's pressing problems. Thus, when the political system stalls on issues for which the public is convinced movement is essential, Congress is seen as the negative, blocking institution, thwarting efforts to solve problems. Congress is not seen simply as failing to address public issues; Congress is seen as obstructionist. The perception that Congress dedicates inordinate attention to the self-interest of members (meaning inordinate attention to special interests) reinforces the public's negative attitude toward Congress. ${ }^{157}$ Violating the maxim

155. See HibBING \& THEISS-MORSE, supra note 140, at 55:

The kind of policy dissatisfaction we picked up [and which we believe contributes to dissatisfaction with the institution] seems to parallel the concept of valence issues [those issues for which the desired ends are not in question, just the means]. Overwhelming sentiment exists that the government should 'do something' about key problems, but the public often demurs from engaging in the crucial debate about the specific means by which something should be done.

156. See id. at 56 ("[C]ongressional power does not emanate from the setting of policy agendas, but from its ability to block what the president wants.").

157. Not everyone lays the problem of Congress's lack of performance at Congress's doorstep. Jane Mansbridge argues that expectations of what Congress must do exceed its capabilities, given the tools available to it. Jane Mansbridge, Social and Cultural Causes of Dissatisfaction with U.S. Government, in Why PEOPLE DON'T TRUST GOVERNMENT 133, 133-34 (Joseph S. Nye, Jr. et al. eds., 1997):

Sociocultural changes have produced new problems, with consequent demands for government solutions. Sociocultural changes have also independently produced rising expectations for government action. Both these trends have generated governmental "overload" - a situation in which citizens ask the government to solve problems it cannot solve, ask the government to do more things (and more incompatible things) than it can do, and ask the government to solve problems without being willing to sustain taxation adequate to finance the efforts that would produce a solution.... $[T]$ hese greater demands on government operate within a system designed to go slow.

Whether the government is failing to accomplish achievable goals or failing because people demand the impossible, the immediate impact is the same: people conclude that government lacks the competence to address the problems the public thinks important. 
that one should either "lead, follow, or get out of the way," Congress too often strikes out, incapable of leading, and unwilling to follow.

\section{Costs}

During the past thirty years, the public perception of government's desirable attributes has changed, and the perceived cost of not reposing trust in the federal government has been declining, making it easier to allocate authority to state and local governments. These current perceptions can be contrasted with the perceptions of an earlier era that encouraged the federalization of much governmental responsibility. Keith Whittington notes three features of the policymaking environment that contributed to the push toward centralization in earlier periods of the twentieth century. ${ }^{158}$ One is the administrative ethic, in which expertise rather than local knowledge is thought to be critical to good policy. ${ }^{159}$ Harkening back to the Progressive Era, the administrative ethic posits that coherence and synopticism are attainable public policy goals, better implemented centrally than filtered through fifty political processes. In contrast, recent years have seen growing strength in the countervailing view that centralized decisionmaking brings rigidity and one-size-fits-all dictates that ought to be replaced by flexible responses to local situations, whether the concern be welfare policy, education, or the environment. Modern understandings of bureaucracies-whether analyzed through the lens of public choice on the right, ${ }^{160}$ through critical legal studies on the left, ${ }^{161}$ or through the cynical journalism of the mass media ${ }^{162}$-also have discredited the Progressive ambition to establish a politics-free administration. Federal programs are as infused with politics as any other. These shifting sensibilities have been accompanied by a growth in state competence in the past thirty years, ${ }^{163}$ so that, to the extent that expertise is still thought essential, the gap between the perceived

\footnotetext{
158. Keith Whittington, Dismantling the Modern State? The Changing Structural Foundations of Federalism, 25 HASTINGS CONST. L.Q. 483 (1998).

159. Id. at 490-93.

160. See generally William Niskanen, BurEAUCRACY AND REPRESENTATIVE GOVERNMENT (1971).

161. See generally Gerald E. Frug, The Ideology of Bureaucracy in American Law, 97 HARV. L. REV. 1276 (1984).

162. See generally Paul Starobin, A Generation of Vipers: Journalists and the New Cynicism, Colum. Journalism ReV., Mar.-Apr. 1995.

163. M. Kent Jennings, Political Trust and the Roots of Devolution, in TRUST AND GOVERNANCE, supra note 127, at 218, 220-22.
} 
competence of state versus national government has narrowed considerably.

The second feature Whittington identifies as contributing to centralization is the growth of the positive state, with its emphasis on the regulatory and redistributive functions of government. ${ }^{164}$ The New Dealers' flirtations with government intervention prompted the confrontations with the Court in Schechter Poultry ${ }^{165}$ and Carter Coal. ${ }^{166}$ Ultimately, the confrontations were resolved by the Court's retreat from judicial superintendence of the reach of federal power. Even though the New Deal never returned to such thoroughgoing intervention in the market economy as the National Industrial Recovery Act, ${ }^{167}$ the regulatory apparatus enabled by the Court's withdrawal was deployed in many different public programs, each with its constituents favoring regulation of various dimensions of American industry and each favoring a centralized bureaucracy corresponding to the national business structure being regulated.

Two of the great social movements of the last thirty years, the civil rights movement and the environmental, health, and safety movement, have been implemented through centralized, positive state structures. In the case of civil rights, state governmental structures were the initial targets of federal policy, so federalization of the issue was thought essential to respond to discrimination and its continuing effects. The environmental, health, and safety movement easily borrowed the rights rhetoric of the civil rights movement. ${ }^{168}$ If every person in America had the right to breathe clean air, the instantiation of that right as federal policy matched the sincerity of the claim of right much more convincingly than leaving the development of policy up to fifty different jurisdictions. Here, states were much more sympathetic to nationalization than in the earlier civil rights

164. Whittington, supra note 158, at 494 .

165. A.L.A. Schecter Poultry Corp. v. United States, 295 U.S. 495, 553 (1935) (invalidating corporate codes of fair competition as unconstitutional delegations of legislative authority).

166. Carter v. Carter Coal Co., 298 U.S. 238, 288-317 (1936) (striking down the Bituminous Coal Conservation Act of 1935); see AlAn BRINKLEY, THE END OF REFORM 38-47 (1995) (summarizing the Roosevelt administration's use of bills like the National Industrial Recovery Act and the Bituminous Coal Act to create structures to govern business and labor to harmonize the economy).

167. National Industrial Recovery Act, ch. 90, 48 Stat. 195, 196 (1933).

168. See Christopher H. Schroeder, Foreword: A Decade of Change in Regulating the Chemical Industry, 46 LAW \& CONTEMP. PROBS. 1, 13 (Summer 1983) ("[E]arly legislation expressed coherent environmental values that could be translated into specific rights to environmental quality shared by all citizens.”). 
struggles. States even advocated national action as a means of ensuring that environmental, health, and safety rules would develop uniformly throughout the country, thereby minimizing competition between states. ${ }^{16}$

In contrast to the major social issues of thirty years ago, today's important issues do not so obviously demand a federal solution. ${ }^{170}$ Earlier federal efforts have accomplished a fair amount of what can be accomplished centrally. The residual question is whether a centralized approach is still preferable to a decentralized approach. ${ }^{171}$ Underaddressed environmental problems, for example, include the control of "non-point" sources of water pollution, "172 "hot spots" of toxic pollutants, ${ }^{173}$ and urban sprawl. ${ }^{174}$ Each of these problems requires intense local involvement. Management of these problems from Washington often is viewed more as a hindrance than as a benefit. ${ }^{175}$ Even national environmental organizations, which rose to prominence because Washington was the lead actor on environmental issues, have begun to stress local strategies for the next generation of environmental problems. ${ }^{176}$

169. See, e.g., Air Pollution-1970: Hearings Before the Subcomm. on Air and Water Pollution of the S. Comm. on Public Works, 91st Cong. 1186 (1970) (statement of Douglas M. Head, Attorney General, State of Minnesota and President, National Association of Attorneys General) ("I would strongly support at least a very careful national review of the [air quality] standards making sure that they comply with a certain national minimum.").

170. The threat of terrorism certainly demands strong federal action. In the wake of the events of September 11, 2001, the renewed emphasis on federal competence to address this threat may have a continuing positive effect on levels of trust. See infra notes 191, 202, 232.

171. Whittington, supra note 158 , at 522 .

172. Debra Knopman, Civic Environmentalism: Tackling Tough Land-Use Problems with Innovative Governance, ENV'T, Dec. 1999, at 26.

173. Sheila Foster, Meeting the Environmental Justice Challenge: Evolving Norms in Environmental Decisionmaking, 30 ENVTL. L. REP. 10,992, 10,992 (2000).

174. Rose A. Kob, Riding the Momentum of Smart Growth: The Promise of EcoDevelopment and Environmental Democracy, 14 TUL. ENVTL. L.J. 139, 153-57 (2000).

175. One reason the federalism decisions are criticized is because the notion that decentralized solutions are more appropriate for modern social problems is only partially accurate. While some problems seem to call for decentralization, others call for continued national and even international attention. For example, many behaviors of international corporations cannot be regulated effectively by states. Nor can global warming or the conservation of fisheries.

176. This shift draws on a tradition within American environmentalism that has dissented from centralized approaches to environmental problem solving. EDWARD ABBEY, THE Monkeywrench Gang (1975), Amory Lovins, Soft Energy Paths: TOWARd A Durable Peace (1977), and E.F. Schumacher, SMAll Is Beautiful (1973), are classic expositions of aspects of this branch of environmental thought. See generally Christopher H. Schroeder, The Evolution of Federal Regulation of Toxic Substances, in GOVERNMENT AND EnVIRONMENTAL Politics 263 (Michael J. Lacey ed., 1989) (demonstrating that existing ad- 
The third feature Whittington identifies as contributing to centralization is the change in public morality that occurred in the early twentieth century. The emerging sense that government should intervene more actively in social and economic activity produced a wave of muckraking journalism exposing the deficiencies of government. ${ }^{177}$ At the time, though, the dominant faces of government in the country were state and local, so these received the brunt of the criticism. ${ }^{178}$ Calls for reforming these levels of government were accompanied by invocations of federal authority as a means to correct or compensate for state and local deficiencies. ${ }^{179}$ In contrast, the repeated and widespread criticisms of government and government programs in recent years have concentrated on the federal government, the new dominant face of government. The federal government receives the lion's share of media attention, so the media's penchant for covering scandal and conflict overwhelmingly highlights federal scandal and corruption, instead of state and local versions of the same thing. ${ }^{180}$ For issues for which public morality insists that the government assume responsibility, state and local governments appear more attractive simply because they have been relatively free of negative media coverage.

Earlier in the century, the public morality associated with federal domestic policy was intended to strengthen the idea of American citizenship and the rights associated with that citizenship. In contrast, the most vocal moral demands of our time are demands for the recognition of diversity. ${ }^{181}$ Diversity finds expression in efforts to expand federal antidiscrimination legislation beyond race, gender, and religion. Other diversity demands cannot be vindicated at the federal level,

ministrative procedures cannot adequately address the problems posed by the numerous chemicals that may be toxic). In parallel fashion, the Court's increased protection of state autonomy draws on a tradition within American constitutional thought that has long dissented from centralization. See, e.g., RAKOVE, supra note 130, at 131-60 (1996) (describing the debate between Antifederalists and Federalists).

177. Whittington, supra note 158 , at $500 \mathrm{n} .75$.

178. Id. at 500 .

179. Id. at 500-01.

180. For discussions of the media's concentration on the coverage of scandal, corruption, and the campaign "horse race," see generally JOSEPH A. CAPPELlA \& KATHLEEN HALL JAmieson, Spiral of Cynicism: The Press And the Public Good (1997); Kathleen HAll JAMIESON, DirTy Politics (1992); ThOMAs E. PATterson, OUt OF ORDER (1994).

181. Whittington, supra note 158, at 516-20. See generally Peter H. Schuck, The Perceived Values of Diversity, Then and Now, 22 CARDOzo L. REV. 1915, 1958-60 (2001) (exploring Americans' attitudes toward diversity). 
though, and proponents of this kind of diversity support the allocation of decisionmaking authority to the lower levels of government.

Although there are countervailing forces that continue to make federalization attractive, perspectives on the administrative ethic, the positive state, and public morality indicate that state and local approaches to many social and economic policies have become more appealing. Whether federal governance is superior to state governance is a much closer question than it was earlier in the century, so people perceive the selection of state over federal power as less costly.

Shifts in public perception of the extent to which federal officials encapsulate our interests, of the federal government's capacity to act competently, and of the costs of removing power from the federal government all contribute to the well-documented, widespread and severe decline in overall trust in the federal government and the reciprocal climb in measures of distrust and cynicism over the past thirty-five years. ${ }^{182}$ The American National Election Study (NES) asks four questions designed to probe the public's trust in government; the answers constitute the data for the NES Trust in Government Index. ${ }^{183}$ The Index provides a useful overall gauge of the public's willingness to repose authority in the federal government. ${ }^{184}$

182. Widespread awareness of the phenomenon probably can be traced to Seymour Lipset and William Schneider's book-length treatment of the decline in trust in all major American institutions that began around 1965. SEYMOUR MARTIN LIPSET \& WILLIAM SCHNEIDER, THE Confidence Gap: Business, Labor And Government in the Public Mind (1983). See generally Why PEOPLE DON'T TRUST GOVERnMENT, supra note 157 (discussing the widespread loss of confidence in, and dissatisfaction with, the government).

183. The Trust in Government Index is constructed from the following items:

How much of the time do you think you can trust the federal government to do what is right - just about always, most of the time, or only some of the time?

Would you say the government is pretty much run by a few big interests looking out for themselves or that it is run for the benefit of all?

Do you think that people in government waste a lot of money we pay in taxes, waste some of it, or don't waste very much of it?

Do you think that quite a few of the people running the government are crooked, not very many are, or do you think hardly any of them are crooked?

The NES Guide to Public Opinion and Electoral Behavior, National Election Studies, available at http://www.umich.edu/ nes/nesguide/toptable/tab5a_5.htm (last visited Aug. 28, 2001) (on file with the Duke Law Journal).

184. The NES Guide to Public Opinion and Electoral Behavior, National Election Studies, available at http://www.umich.edu/ nes/nesguide/graphs/g5a_5_1.htm (last visited Aug. 19, 2001) (on file with the Duke Law Journal). 


\section{TRUST IN GOVERNMENT INDEX 1958-2000}

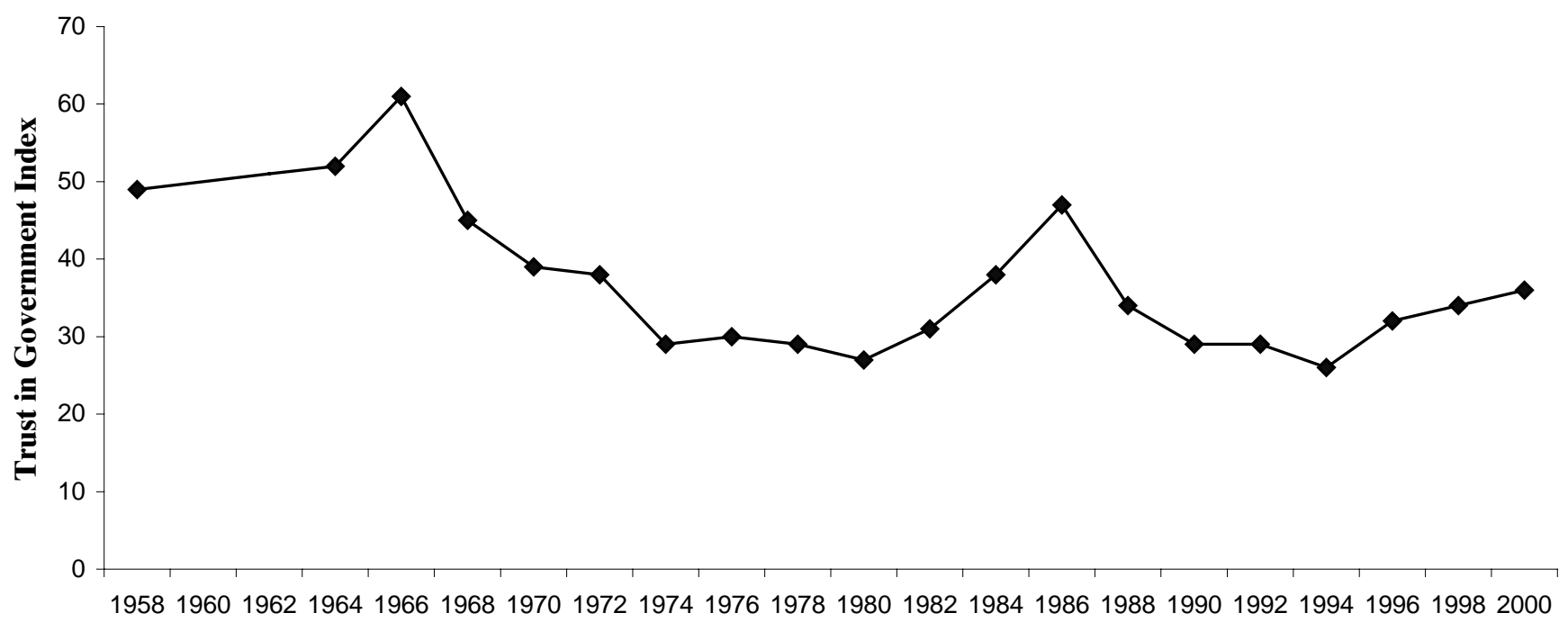


Since 1964, NES has asked people, "How much of the time do you think you can trust the government in Washington to do what is right?" 185 In 1964, the percentage of people responding either "just about always" or "most of the time" was $76 \% .{ }^{186}$ Over the next two years, that percentage began to decline. ${ }^{187}$ In a 1995 Gallup poll, the percentage responding "just about always" or "most of the time" stood at $23 \%{ }^{188}$ in a 1999 Gallup poll, it was $34 \%{ }^{.189}$ in a 2001 CBS News poll, 27\%. ${ }^{190}$ Not even terrorist attacks on the World Trade Center and the Pentagon on September 11, 2001, which has caused many Americans to look to the federal government for a response, raised the percentage to earlier levels. After the attacks, the figure remained more than ten percentage points lower than the 1964 figure. $^{191}$

This distrust of Washington has concrete political consequences. The 1994 elections saw the Republicans benefit from this distrust, gaining control of both houses of Congress for the first time in forty years. Immediately prior to that election, attitudes toward Congress equaled or exceeded all-time lows. ${ }^{192}$ There seems little question that

185. The NES Guide to Public Opinion and Electoral Behavior, National Election Studies, available at http://www.umich.edu/ nes/nesguide/toptable/table5a_1. htm (last visited Aug. 22, 2001) (on file with the Duke Law Journal).

186. Id.

187. Id.

188. Gallup Poll of August 11, 1995, Roper Center for Public Opinion Research, at http:// web.lexis-nexis.com/universe (last visited Oct. 7, 2001) (accession number 0249330) (on file with the Duke Law Journal).

189. Gallup Poll of February 7, 1999, Roper Center for Public Opinion Research, at http:// web.lexis-nexis.com/universe (last visited Oct. 7, 2001) (accession number 0325385) (on file with the Duke Law Journal).

190. CBS News Poll of January 15, 2001, Roper Center for Public Opinion Research, at http://web.lexis-nexis.com/universe (last visited Oct. 7, 2001) (accession number 0377226) (on file with the Duke Law Journal).

191. A Washington Post-ABC News poll after the terrorist attacks showed that this measure of trust in the federal government had climbed to 64 percent. Richard Morin \& Claudia Deane, Poll: Americans' Trust in Government Grows, WASH. Post OnLINE, Sept. 28, 2001, at http:// www.washingtonpost.com (on file with the Duke Law Journal). For further discussion of this sharp change in trust in government and its implications for the direction of federalism doctrine, see infra notes 202 and 232.

192. For instance, the percentage of people having a great deal of confidence in Congress was down to 7\% prior to the 1994 election. National Opinion Research Center General Social Survey 1993, Roper Center for Public Opinion Research, at http://web.lexis-nexis.com/universe (last visited Oct. 15, 2001) (accession number 0201974) (on file with the Duke Law Journal). Perhaps the most telling indicator is the response when people were asked whether they approved of the job their own representative had been doing. In contemporary times, this figure always has been much higher than the figure for the approval of Congress overall, due to the 
voters were fed up with so many years of Democratic control and were hoping that new leadership would be superior to the old. Nonetheless, the change in majority status in the 1994 elections had little effect on the public's overall opinion of Congress. Even during the "honeymoon" period immediately following the 1994 election, 56\% of those polled felt that government programs and policies hindered their family's ability to achieve the American dream; only $31 \%$ felt they helped. ${ }^{193}$

While willingness to give authority to the federal government has been declining, willingness to give authority to state and local governments has been rising. In the late 1960s, data based on a national cross-sectional survey showed that people trusted the federal government more than either the state or local government. ${ }^{194}$ During the 1970 s, however, "the relative standing of the national government suffered an extraordinarily sharp decline," a decline that was visible "regardless of region, partisanship, urbanicity, or race." 195

Not only have relative measures of trust in federal, state, and local governments changed dramatically, so have absolute levels. The empirical data for evaluating absolute levels of confidence in state and local levels of government are much thinner than the data about trust in the federal government collected in the American National Election Study. Still, the data that exist have been described as "startling." 196

Whereas the national government suffered a loss of over 30 percent in terms of trust and confidence, the state level dropped by half that much and local government scarcely at all. Clearly, the tar brush did

ability of representatives to use their offices to cultivate positive approval ratings at home. Prior to the 1994 election, this figure was below $50 \%$, down from the $64 \%$ approval rating enjoyed as recently as 1990. Compare ABC News-Washington Post Poll of October 20, 1994, Roper Center for Public Opinion Research, at http://web.lexis-nexis.com/universe (last visited Oct. 15, 2001) (accession number 0229428) (on file with the Duke Law Journal), with ABC News-Washington Post Poll of October 10, 1990, Roper Center for Public Opinion Research, at http://web.lexisnexis.com/universe (last visited Oct. 15, 2001) (accession number 0140434) (on file with the Duke Law Journal).

193. Council for Excellence in Government Poll of March 16, 1995, Roper Center for Public Opinion Research, at http://web.lexis-nexis.com/universe (last visited Oct. 7, 2001) (accession number 0236535) (on file with the Duke Law Journal).

194. Jennings, supra note 163 , at 221 (providing the responses to the following question posed by the 1968 National Election Studies: "In your case, do you have more faith and confidence in the national government, in the government of this state, or in the local government about here?").

195. Id. at 225 .

196. Id. at 229. 
not sweep with equal vigor across all levels. Disenchantment with the national government did not produce commensurate disenchantment at lower levels. Alternatively, the factors feeding the growing distrust of the federal government did not have as much impact at the lower levels. ${ }^{197}$

Although the lack of survey research in the early twentieth century prevents comparison of these data with data from the Progressive Era and the Great Depression, current reevaluations of government appear to be the mirror image of those that occurred during these prior eras.

In the early nineteenth century, individuals looked to state and local government for the services they expected the government to provide. ${ }^{198}$ Charges of corruption as well as changing expectations produced dissatisfaction with the performance of those governments. The perceived incapacity of state governments to cope with national problems grew as the economy nationalized and reached a high water mark when the country slipped into the Great Depression. ${ }^{199}$ In a tremendous wave of legislative activity, the federal government took on the responsibility of constructing government programs to move the economy forward. ${ }^{200}$ The two successful wars that bracketed the Great Depression undoubtedly contributed to a belief in the competence of the federal government. ${ }^{201}$ The public turned to the federal govern-

\footnotetext{
197. Id.

198. Fire fighting, police, public education, sewage disposal, and road and bridge maintenance have been local activities historically. Before the rise of economic regulation and redistributive programs, these activities constituted the vast bulk of what people expected from their government.
}

199. During the Great Depression, state and local governments were capable of stop-gap measures, such as Minnesota Governor Floyd Olson's moratorium on mortgage foreclosures, but the country despaired of the political process's inability to cope with the country's economic ills until President Roosevelt assumed office and inspired new confidence in the nation. See William E. Leuchtenburg, Franklin D. RooseVelt and the New Deal, 1932-1940, at 47 (1963) ("Two weeks after Roosevelt took office, the country seemed a changed place. Where once there had been apathy and despondency, there was now an immense sense of movement.").

200. See id. at 41-62 (describing legislation in President Roosevelt's first hundred days).

201. The immediate aftermath of World War II brought a prosperity that removed much of the justification for New Deal interventions in the economy. The period saw the dismantling of a number of New Deal programs. See AlAN BRINKLEY, LIBERALISM AND ITS DisCONTENTS 94, 97 (1998) ("To them the end of the Depression removed whatever justification there had been for the New Deal interventions into the economy and mandated a return to a less regulated market, a less profligate government, and a less expansive welfare state."). However, when Keynesian economics soon called for the use of fiscal tools to promote economic prosperity, and when the war on poverty and then the environmental and consumer movements later called for 
ment during the first half of the century because the federal government registered well on each of the elements of trust: encapsulated interest, competence, and costs. ${ }^{202}$

Because state governments appear to have fared better than the federal government on the elements of encapsulated interest, competence, and costs, they have become more attractive options for the trust that is being withdrawn from the federal government. This shift in trust has manifested itself politically in a desire to remove power from the federal government and give it to the states. ${ }^{203}$ Part $\mathrm{V}$ of this Essay proposes a causal connection between distrust of the federal government and the Court's federalism jurisprudence.

\section{TRUST AND FEDERALISM DOCTRINES}

A lack of trust in the federal government provides a reason to be unenthusiastic about granting the federal government more decisionmaking authority and provides a reason to cut back on the authority the federal government already has. One link between the decline in trust in the federal government and political decisions allocating authority to the states is thus a propositional, or reason-giving one. This propositional link is not the only link between these two, however. In addition to the reasons people make decisions, cognitive psychologists stress how affective or attitudinal elements also play a

government response, federal programs proliferated because "the New Deal conception of the state-a national government actively prepared to take on whatever functions seemed necessary to ensure economic prosperity-[had become] an accepted fact." Robert L. Rabin, Federal Regulation in Historical Perspective, 38 STAN. L. REV. 1189, 1263-64 (1986).

202. This analysis is consistent with the revival of trust in the federal government that has occurred since the World Trade Center and the Pentagon were attacked on September 11, 2001. See supra note 191. When it comes to providing for the national defense, citizens have confidence that the interests of elected officials coincide with their own. Officials reinforce this sense of shared interest through statements proclaiming that partisanship is being put aside in favor of bipartisan support for the president. Under such circumstances, citizens trust the federal government because they strongly believe that the interest in national defense is an encapsulated interest. The Vietnam War notwithstanding, citizens also have confidence in the competence of the American armed forces. (In fact, the failure in Vietnam is often portrayed as a failure by politicians to permit American troops to employ all of the tools at their disposal.) In the wake of the terrorist attacks, therefore, Americans' faith in the competence of the federal government is also strong. Finally, the costs of not reposing trust in the only governmental body with the capacity and legal authority to provide for the national defense appear to be extremely high. Although trust in the federal government has risen since the terrorist attacks, it is too early to say whether this confidence in the federal government to defend the nation will carry over to improve confidence in the government with respect to domestic programs. For further discussion, see infra note 232.

203. See supra notes $170-74$ and accompanying text. 
role in their thinking and reasoning. Psychologists now believe that people formulate favorable or unfavorable judgments about objects of their attention that are subsequently stored in their memories as an evaluative or affective "tag." ${ }^{204}$ Subsequently, the "very same mechanism that brings thoughts into consideration also carries the affective coloration of these thoughts to mind." 20.

The propositional, or reason-giving, role of trust has special significance to the theory of judicial decisionmaking employed in externalist models. Under the externalist view, judges decide cases so as to satisfy their preferences. Their distrust of the federal government contributes to their decision by providing them with a reason to prefer limitations on federal power.

The affective role of trust has special significance in internalist theories of judicial decisionmaking. The negative impression of the federal government produced by sustained periods of distrust can tag the idea of federal authority with a negative or hostile affect. That negative tag subsequently influences judicial reasoning in cases about federal authority, not by giving judges reasons for deciding against federal power, but by influencing what kinds of arguments judges find most persuasive.

The theory of reasoning that posits these connections is known as the theory of motivated reasoning. It states that when individuals have a "wish, desire, or preference that concerns the outcome of a given reasoning task," this motivation "may affect reasoning through reliance on a biased set of cognitive processes: strategies for accessing, constructing, and evaluating beliefs" by providing a "directional goal" for their reasoning processes. ${ }^{206}$ That directional goal influences the results of the reasoning process because people draw on an existing supply of beliefs, evaluation techniques, and inference rules when confronted with a problem. ${ }^{207}$ At any one time, they do not draw on their entire supply of beliefs, techniques, and rules. In fact "people

204. See, e.g., Milton Lodge \& Charles Taber, Three Steps Toward a Theory of Motivated Reasoning, in ElEMENTS OF REASON: COGNITION, CHOICE AND THE BOUNDS OF RATIONALITY 183, 183-86 (Arthur Lupia et al. eds., 2000) (describing the theory of cognition in which all social concepts are affect-laden and in which the affects associated with social concepts are "stored directly with the concept in long-term memory").

205. Id. at 196.

206. Ziva Kunda, The Case for Motivated Reasoning, 108 PSYCHOL. BuLL. 480, 480 (1990).

207. See id. ("[This] discussion is restricted to cases in which motivation can be construed as affecting the process of reasoning: forming impressions, determining one's beliefs and attitudes, evaluating evidence, and making decisions."). 
access different beliefs and rules on different occasions: They endorse different attitudes, express different self-concepts, make different social judgments, and use different statistical rules."208

The theory of motivated reasoning posits that directional goals regarding the outcome of the reasoning process are among the conditions that influence the beliefs, rules, evaluations, and explanations that people employ and find persuasive. ${ }^{209}$ A growing body of evidence supports this theory. ${ }^{210}$ For instance, in one study women who consumed large amounts of caffeine were less convinced by an article claiming that caffeine posed risks for women than were women who consumed small amounts of caffeine. ${ }^{211}$ Men, who one would expect to have less of a directional goal with respect to the evaluation of the article than women, showed no such differential effects. ${ }^{212}$ Similarly, those who believed that capital punishment deters crime were more likely to criticize a disconfirming study on the basis of "insufficient sample size, nonrandom sample selection, or absence of control for important variables" than were those who thought that capital punishment was not a deterrent. ${ }^{213}$ In short, "[p]eople are more likely to arrive at those conclusions that they want to arrive at."214

Motivated reasoning does not mean that "anything goes" as long as it leads to the desired conclusion. " ${ }^{215}$ "W]e are not at liberty to conclude whatever we want to conclude simply because we want to. Even when we are motivated to arrive at a particular conclusion, we are also motivated to be rational and to construct a justification for our desired conclusion that would persuade a dispassionate observer." ${ }^{216}$

208. Id. at 483 (citations omitted).

209. See id. ("The proposed mechanisms are based on the assumption that directional goals may influence which beliefs and rules are accessed and applied on a given occasion.”).

210. See Ziva Kunda, Social Cognition 212-35 (1999) (summarizing evidence that motivated reasoning theory is superior to a purely cognitive account of reasoning).

211. See Ziva Kunda, Motivated Inference: Self-Serving Generation and Evaluation of Causal Theories, 53 J. PERSONALITY \& SOC. PSYCHOL. 636, 642-44 (1987) ("Thus it appears that those subjects who stood to suffer personal implications if the evidence were true were more likely to doubt its truth.").

212. Id.

213. Kunda, supra note 206, at 490 (citing C.G. Lord et al., Biased Assimilation and Attitude Polarization: The Effects of Prior Theories on Subsequently Considered Evidence, $37 \mathrm{~J}$. PERSONALITY \& SOC. PSYCHOL. 2098 (1979)).

214. Id. at 495.

215. See id. at 486 ("[M]otivated self-characterizations often appear to be constrained by prior self-knowledge, and these constraints provide indirect evidence that motivation biases selfconceptions by biasing the memory search for relevant information.").

216. KUNDA, supra note 210, at 224. 
As Ziva Kunda observes, "[We] are constrained by [our] prior beliefs about the acceptability of various procedures." ${ }^{217}$

The influence of directional goals, furthermore, seems to be lessened when the subject expects that others will evaluate the results of his reasoning. Subjects who expected to be evaluated or who expected their judgments to be made public relied less on the cognitive biases that are thought to lead to less defensible judgments, such as stereotyping, anchoring when making probability judgments, or excessively attributing causality to individuals despite the presence of environmental constraints. ${ }^{218}$ On the other hand, directional goals tend to be influential when the issue to be analyzed is complex or when the reasoner possesses a rich body of knowledge; "it is sophisticates who typically hold the strongest attitudes, with the most confidence, and who have the most facts at hand, thereby making them more able to assimilate supporting evidence and better equipped to discredit arguments that challenge their established beliefs or attitudes." $" 219$

Judicial reasoning appears to exhibit an interesting constellation of features, many diminishing or increasing the influence of directional goals on judges' reasoning processes. ${ }^{220}$ On the one hand, judges expect their opinions to be evaluated. In the case of the Supreme Court, that review process occurs mostly outside the judiciary, at the hands of elected officials, the public, and the scholarly community. Public scrutiny generally is thought to affect judicial behavior, however. On the other hand, the materials, evaluation techniques, and inferential rules of constitutional reasoning are rich, and judges are sophisticated in deploying them. Judges can invoke arguments based on originalist understandings of the Founding, including the early Con-

\footnotetext{
217. Kunda, supra note 206, at 490.

218. See id. at 481 (citing studies).

219. Lodge \& Taber, supra note 204, at 211.

220. Little empirical work has tested the general applicability of these findings to judges. There has been work, however, on the susceptibility of judges to a set of cognitive illusions that have been studied extensively outside of the judicial context. Chris Guthrie, Jeffrey Rachlinski, and Andrew Wistrich have studied whether judicial reasoning showed the effects of anchoring, framing, the hindsight bias, the egocentric bias, and the representative heuristic. "Although the judges in our study appeared somewhat less susceptible to two of these illusions (framing effects and the representative heuristic) than lay decision makers ... each of the five illusions ... had a significant impact on judicial decision making. Judges, it seems, are human." Chris Guthrie, Jeffrey J. Rachlinski \& Andrew J. Wistrich, Inside the Judicial Mind, 86 CORNELL L. REV. 777, 778 (2001). As humans, judges should show the effects of motivated reasoning (which also has been studied extensively on lay decisionmakers. See infra notes 229-38 and accompanying text.).
} 
gresses, ${ }^{221}$ analogical reasoning, ${ }^{222}$ sources incorporated by reference, ${ }^{223}$ historical tradition, ${ }^{224}$ the implicit premises underlying the Constitution, ${ }^{225}$ and claims of special status for suspect classes or fundamental interests, ${ }^{226}$ among others. ${ }^{227}$

This Essay will not attempt to develop a full-blown theory of constitutional reasoning. Any adequate theory will support the conclusion that many constitutional questions do not have inevitable answers. Diverse formulations of judicial reasoning, stressing different argument types, making different evaluations of evidence, and drawing different inferences from available legal materials-all within the range of professional respectability - can lead to different conclusions. Even if lines of argument, once adopted, constrain subsequent judgments through the requirements of plausible consistency (a necessary element of any respectable system of legal reasoning purporting to uphold the rule of law), ${ }^{228}$ the initial process of reasoning was less constrained.

221. See, e.g., Bowsher v. Synar, 478 U.S. 714, 723 (1986) (rejecting any role for Congress in the removal of executive officers on the basis of debates on the subject in the First Congress).

222. See, e.g., Freytag v. Comm'r, 501 U.S. 868, 897 (1991) (Scalia, J., concurring) (analogizing the resolution of a jurisdictional issue for an Article I court to the resolution of a similar issue in an Article III context).

223. See, e.g., Colgrove v. Battin, 413 U.S. 149, 154 (1973) (relying upon an understanding of the common law at the time of the Framers to interpret the Seventh Amendment's guarantee of a jury trial).

224. See, e.g., Michael H. v. Gerald D., 491 U.S. 110, 123 (1989) (relying upon the history and tradition of the country to establish the contours of a due process right).

225. See, e.g., Alden v. Maine, 527 U.S. 706, 713 (1999) (relying upon state sovereignty as a background condition for ratification of the Constitution to bar the federal government from subjecting a state government to suit in state court without state waiver of sovereign immunity).

226. See, e.g., City of Richmond v. J.A. Croson Co., 488 U.S. 469, 493 (1989) (holding that strict scrutiny must be applied to all government programs involving racial classifications).

227. Various scholars have attempted to catalogue permissible types of legal or constitutional arguments. Philip Bobbitt, for example, identifies six types: historical, textual, structural, doctrinal, ethical, and prudential. PHILIP BobBITt, CONSTITUTIONAL INTERPRETATION 12-13 (1991).

228. See id. at 119:

The claim is usually that we (or a judge) must know when to accept or reject a particular argument according to a comprehensive, consistent rule; that this is the only way that we can apply the law rather than our personal preferences; if we have no such rule, then the claim that we are acting from motives other than our preferences is a sham, and the respect due to our decisions - the legitimacy they enjoy—should be withdrawn.

See also Tom Grey, The New Formalism, Working Paper No. 4, Stanford Public Law and Legal Theory Working Paper Series (1999), at 1-5, at http://papers.ssrn.com/pape.taf?abstract_id= 200732 (last visited Sept. 1, 2000) (on file with the Duke Law Journal) (defining rule of law values as determinacy, fidelity, and transparency, which together place a premium on consistency). 
This general sketch of judicial reasoning can be combined with motivated reasoning theory to construct an internalist account of the relationship between federalism doctrines and public distrust of government. Justices develop opinions about the desirability of allocating decisionmaking authority to various levels of government, just as other citizens do. These opinions are linked as negative affective tags to concepts of federal authority and centralized power, among others. When these cognitive concepts and their associated tags are activated, as when a federalism dispute comes before the Court, they provide directional goals in a process of motivated judicial reasoning, which tends to draw upon beliefs, techniques, and inferential rules supporting the desired conclusion. The influence of those prior evaluations does not function as an external preference that Justices attempt to satisfy strategically. Instead, their influence operates internally to the reasoning process, conditioning the beliefs, arguments, and evidence the Justices find persuasive.

Externalists see a direct strategic connection between judicial policy preferences and judicial decisions. Traditional internalists assert that judges are able to resist allowing their policy preferences to affect outcomes. Their ideal is Justice Oliver Wendell Holmes, as he described his own role. Holmes once wrote to Harold Laski about a case involving a federal statute. "I hope and believe," he wrote, "that I am not influenced by my opinion that it is a foolish law. I have little doubt that the country likes it and I always say, as you know, that if my fellow citizens want to go to Hell I will help them. It's my job." ${ }^{229}$ The theory of motivated reasoning, though, suggests that there is a third explanation for how judges think: judges may be successful, at least some of the time, in preventing their policy preferences from serving as the conscious objective of their decisionmaking, and yet those "private" preferences can provide directional goals that affect the arguments and evidence judges find persuasive.

I know of no empirical studies testing this theory directly on legal reasoning. ${ }^{230}$ I believe, however, that any lawyer who has litigated a case at some time has had an experience that speaks to the explanatory power of motivated reasoning. Lawyers are trained to advocate

229. Oliver W. Holmes, Letter from Holmes to Harold J. Laski (Mar. 4, 1920), in 1 Holmes-LASKi LeTters: THE CORRESPONDENCE OF Mr. Justice Holmes AND HAROLD J. LASKI, 1916-1935, at 248-49 (Mark DeWolfe Howe ed., 1953).

230. But see supra note 220 (describing a study on the susceptibility of judges to a set of cognitive illusions that have been studied outside the judicial context). 
vigorously for their clients, a task that involves presenting the best legal arguments to advance their clients' interests. Finding the best argument for a client does not mean, of course, that one has found the best argument in the case-the best argument of the other side might be better. This is not, however, how lawyers experience the process of analyzing facts, researching arguments, testing theories, and developing their eventual legal position. Because lawyers are motivated to find persuasive arguments to support their clients' positions, the theory of motivated reasoning suggests that they will find arguments, evaluative techniques, and evidence that vindicate their clients' positions to be the most persuasive. ${ }^{231}$ More often than not, lawyers become convinced not only that they have found the best argument for their side, but that their argument is superior to the other side's argument.

The theory of motivated reasoning, then, proposes that Justices' opinions about the trustworthiness of the federal government will provide them with a directional goal that influences what elements of judicial reasoning they will select (in other words, find persuasive) in reaching federalism decisions. ${ }^{232}$ They will be constrained by the

231. This hypothesis could be tested. Through some appropriate screening, a person could compile a list of litigated cases in which the ex ante probabilities of prevailing were approximately one-half for each side. The person then could question the lawyers for each side to find out if they believed they had better legal arguments than their opponents. If the motivated reasoning hypothesis is correct, the percentage of both winning and losing attorneys responding affirmatively ought to be greater than fifty percent.

232. Some analysts have suggested that the increased trust in the federal government in the aftermath of the September 11,2001, attacks on the World Trade Center and the Pentagon may alter the course of the Court's federalism decisions by encouraging the Justices to permit more expansive federal powers. See, e.g., Linda Greenhouse, Will the Court Reassert National Authority?, N.Y. TIMES, Sept. 30, 2001, § 4, at 14 . While it is too early to tell whether this will be true, the analysis developed in this Essay suggests several preliminary conclusions. First, the increase in confidence in the federal government is entirely consistent with the Essay's hypothesis. Application of the three elements of trust to post-September 11 events explains why a revival of trust has occurred. See supra note 202. Second, whether the current revival of trust will affect judicial thinking about federalism will depend in the first instance on whether the revival is lasting. Although this Essay has not emphasized this point, positive regard for the federal government may need to exist for many years before it influences the internal thought processes of sitting Justices. Robert Putnam has suggested that "there is a real chance that at least a portion of the recent gains in public confidence and civic engagement can be retained, but only if political leaders, civic and religious groups work quickly to harness the current wave of good feelings sweeping the country." Morin \& Deane, supra note 191. By comparison, this Essay has pointed to a roughly thirty-year period in which negative regard for the federal government was a prevalent feature of public discourse. See supra Part IV. Third, even assuming that trust in the federal government remains strong for many years, whether this increased trust will have an effect on federal decisionmaking on domestic matters will depend upon whether people draw a distinction between national defense-related trust and trust related to domestic matters. This 
bounds of professional acceptability. Arguments based on doctrine, precedent, original understanding, and other tools of judicial reasoning and interpretation delineate the possible avenues of decision. The Justices' directional goals make some of those avenues more attractive, thereby influencing the ultimate destination.

The role of legal reasoning in the judicial process is similar to the role of ideas in the political process, as described by Max Weber: "Not ideas, but material and ideal interests, directly govern men's conduct. Yet very frequently the 'world images' that have been created by 'ideas' have, like switchmen, determined the tracks along which action has been pushed by the dynamics of interest.",233 In Weber's case, ideas create the possibilities for action among which individuals believe themselves free to choose. In the judicial case, existing doctrine, arguments, and settled interpretations of prior decisions operate as the switchmen determining which tracks the reasoning process can most readily follow. However well specified these doctrinal tracks become, they still may lead to multiple destinations. Morrison $^{234}$ and Lopez, ${ }^{235}$ for instance, depend significantly on a historical recognition that the Commerce Clause power does not grant a general police power to the federal government. ${ }^{236}$ There must be some regulatory space that can be reached only by state authority. Morrison and Lopez maintain that a dividing line exists between commercial and noncommercial activities. ${ }^{237}$ The precise contours of that boundary are scarcely well-defined, however, and it will take the

Essay's analysis suggests that such a distinction could be drawn. For instance, even if the events of September 11, 2001, increase confidence in all levels of government, there still will be less cost in cabining federal power over domestic issues compared to cabining federal power over national defense. See Ernest Young, The Balance of Federalism in Unbalanced Times: Should the Supreme Court Reconsider Its Federalism Precedents in Light of the War on Terrorism?, at http://writ.news.findlaw.com/commentary/20011010_young.html (last visited Oct. 23, 2001) (on file with the Duke Law Journal) (arguing that the Court should continue to follow the course of its most recent federalism decisions).

233. MaX Weber, From MaX Weber: Essays on Sociology 280 (H.H. Gerth \& C. Wright Mills eds., 1958).

234. Morrison v. United States, 529 U.S. 598, 608 (2000).

235. United States v. Lopez, 514 U.S. 549, 556-57 (1995).

236. See Morrison, 529 U.S. at 607 (relying on the review of the Commerce Clause's history in Lopez for the proposition that limits to the commerce power always have been recognized); Lopez, 514 U.S. at 553 (noting that the Court in Gibbons v. Ogden, 22 U.S. (9 Wheat.) 1 (1824), "acknowledged that limitations on the commerce power are inherent in the very language of the Commerce Clause").

237. See Morrsion, 529 U.S. at 610-11 (emphasizing the commercial nature of activities that legitimately can be regulated); Lopez, 514 U.S. at 551, 559-60 (same). 
rendering of many more decisions involving diverse fact situations to flesh out its meaning. ${ }^{238}$ Under the theory offered here, a majority of the Court has begun to try to articulate a formal dividing line between what is local and what is federal for Commerce Clause purposes. The fact that four Justices strongly favor getting off the tracks the Court majority has chosen shows that the account given here is not a deterministic one. It presents an argument as to why the shift in favor of the states seems more reasonable now than it would have thirty years ago. A number of alternative doctrinal tracks remain open. This Essay has suggested that part of the explanation for why new doctrinal directions are being explored is that thirty years of distrust of the federal government have made more attractive the paths of decisionmaking that lead to a reallocation of government power.

\section{CONCLUSION}

In discussing the causal role of political ideas, Geoffrey Garrett and Barry Weingast argue that ideas "are a dime a dozen.",239 "For every idea that appears to play a major role in politics, tens of thousands play no role at all. Rarely do scholars explain why the idea they study had an impact when so many others did not."240 Additionally, they argue that "too often an argument about the role of ideas amounts to an assertion that an idea mattered without a persuasive explanation for why or how it had influence." ${ }^{241}$

The theory of motivated reasoning provides an explanation for how ideas about trust and distrust of government may have influenced the recent federalism cases. Those ideas do not enter the picture as policy preferences the judges consciously pursue, but rather as internal influences upon the reasoning process of the Justices.

\footnotetext{
238. Subsequent decisions have not shed much light on the distinction. The Court has intimated that the Commerce Clause does not extend federal authority to the regulation of nonnavigable, isolated, intrastate waters, but did so in a way that did not further elucidate the meaning of "commercial." See Solid Waste Agency v. United States Army Corps of Eng'rs, 531 U.S. 159, 171-72 (2001) ("We thus decline ... [to hold] that isolated ponds, some only seasonal, wholly located within two Illinois counties, fall under $\S 404(a)$ 's definition of 'navigable waters' because they serve as habitat for migratory birds.").

239. Geoffrey Garrett \& Barry R. Weingast, Ideas, Interests and Institutions: Constructing the European Community's Internal Market, in IDEAS AND FOREIGN POLICY 173 (Judith Goldstein \& Robert O. Keohane eds., 1993).

240. Id. at 203.

241. Id.
} 
This account provides an explanation for the perceived correlation between judicial decisions and presumed judicial policy preferences while at the same time preserving a defensible version of the internalist account of judicial decisionmaking. Although the application of motivated reasoning to judicial decisionmaking requires further refinement, it at least provides a plausible causal connection between attitudes toward government and the recent federalism decisions.

As for Garrett and Weingast's first question (why does any particular idea have an impact?), the presence of a large, centralized, and active federal government since World War II would seem to make the public's attitudes toward the capabilities, motivating interests, and costs of relying upon the federal government loom large. Many people have developed a bias against the national government. Deciding where decisionmaking authority should lie is the predominant function of constitutional adjudication in general, and federalism adjudication in particular. ${ }^{242}$ Accordingly, an evaluation of the trustworthiness of the federal government that assigns a negative connotation to enlargements of federal power ought to produce a directional goal capable of influencing the reasoning process of elected officials, the general public, and even judges.

This Essay has not attempted to evaluate its theory in comparison to other possible explanations for the federalism decisions; instead it simply has stated the theory and explained why it makes sense. I have argued that the theory has certain advantages over either the internal or external account taken alone. Nonetheless, other explanations may be better. The Court may be making a blatant grab for power, in which the conservative Justices strategically advance their policy preferences. Bush v. Gore ${ }^{243}$ supports that interpretation; the same five-Justice majority responsible for the federalism changes may have effectively handed the presidential election to George W. Bush by stopping the recount in Florida. It has been claimed that these five Justices effectuated a "constitutional coup," seeking to secure their jurisprudential legacy through further strategic appointments by a Republican president. ${ }^{244}$

\footnotetext{
242. See supra notes 119-24 and accompanying text.

243. 531 U.S. 98 (2000).

244. See, e.g., Balkin \& Levinson, supra note 88, at 1050 (referring to Bush v. Gore as a constitutional coup); Bruce Ackerman, Anatomy of a Constitutional Coup, LONDON REV. OF BOOKS, Feb. 8, 2001, at 3 (same).
} 
Matters of no small significance hang on which interpretation better describes events. Indeed, should the constitutional coup picture be the truer one, and should we move into a period that solidifies and extends the Court's recent federalism changes, those changes not only would fail to satisfy Ackerman's four-step road to nontextual legitimacy, they also would be illegitimate under almost any other theory. On the other hand, should the motivated reasoning account be the better one, the recent turn in constitutional interpretation may acquire a greater claim to legitimacy. Unfortunately, distinguishing these two possibilities would require access to the internal thought processes of the Justices, which is unlikely. The interpretive battle over Bush v. Gore inevitably will be fought on terrain where motivated reasoning will continue to be in evidence-in the stances taken by advocates of either side-regardless of whether it explains the federalism decisions.

However the legitimacy question is answered, the account offered here suggests that Supreme Court doctrine aligns itself with broader political dispositions toward the allocation of decisionmaking authority, not only through strategic appointments, but also by motivated reasoning. Perhaps this explains why so much of the constitutional text has remained unchanged for so long-it is a text with enough flexibility to bend with political change. 